NBER WORKING PAPER SERIES

\title{
ON SECULAR STAGNATION IN THE INDUSTRIALIZED WORLD
}

\author{
Łukasz Rachel \\ Lawrence H. Summers \\ Working Paper 26198 \\ http://www.nber.org/papers/w26198
NATIONAL BUREAU OF ECONOMIC RESEARCH
1050 Massachusetts Avenue
Cambridge, MA 02138
August 2019

The paper was originally prepared for the Brookings Papers on Economic Activity Spring 2019 Conference. The views expressed here are solely of the authors and not of the Bank of England, its policy committees, or the National Bureau of Economic Research. We are grateful to the editors Janice Eberly and James Stock, and our discussants Arvind Krishnamurthy and Gauti Eggertsson, for their detailed comments that much improved the paper. We also thank Ricardo Reis, Daniele Siena, Anna Stansbury and participants at the NuCamp conference at Oxford for insightful comments on the earlier versions. Lukasz thanks the Department of Economics at Harvard University, where much of this project was completed during his visit as a Fulbright Fellow, and the US-UK Fulbright Commission for financial support.

NBER working papers are circulated for discussion and comment purposes. They have not been peer-reviewed or been subject to the review by the NBER Board of Directors that accompanies official NBER publications.

(C) 2019 by Łukasz Rachel and Lawrence H. Summers. All rights reserved. Short sections of text, not to exceed two paragraphs, may be quoted without explicit permission provided that full credit, including (C) notice, is given to the source. 
On Secular Stagnation in the Industrialized World

Łukasz Rachel and Lawrence H. Summers

NBER Working Paper No. 26198

August 2019

JEL No. E43,E44,E50,E60,F41

\begin{abstract}
We argue that the economy of the industrialized world taken as a whole is currently - and for the foreseeable future will remain - highly prone to secular stagnation. But for extraordinary fiscal policies, real interest rates would have fallen much more and be far below their current slightly negative level, current and prospective inflation would be further short of the two percent target levels and past and future economic recoveries would be even more sluggish. We start by arguing that, contrary to current practice, neutral real interest rates are best estimated for the bloc of all industrial economies given capital mobility between them and relatively limited fluctuations in their aggregated current account. We show, using standard econometric procedures and looking at direct market indicators of prospective real rates, that neutral real interest rates have declined by at least 300 basis points over the last generation. We argue that these secular movements are in larger part a reflection of changes in saving and investment propensities rather than the safety and liquidity properties of Treasury instruments. We highlight the observation that levels of government debt, the extent of pay-as-you-go old age pensions and the insurance value of government healthcare programs have all ceteris paribus operated to raise neutral real rates. Using estimates drawn from the literature, as well as two general equilibrium models emphasizing respectively life-cycle heterogeneity and individual uncertainty, we suggest that the "private sector neutral real rate" may have declined by as much as 700 basis points since the 1970s.
\end{abstract}

Łukasz Rachel

Bank of England

Threadneedle Street

London, EC2R 8AH

United Kingdom

lukasz.rachel@bankofengland.co.uk

Lawrence H. Summers

Harvard Kennedy School of Government

79 JFK Street

Cambridge, MA 02138

and NBER

lhs@harvard.edu

Online appendices are available at: https:/www.nber.org/data-appendix/w26190/ 


\section{Introduction}

Long after the 2008 financial crisis, real interest rates in the economies of the industrialized world remain very low by recent historical standards, central banks balance sheets are inflated, government debt and deficit levels are high and yet nominal GDP growth remains too low for the achievement of 2 percent inflation targets. This has led to a revival of interest in the secular stagnation hypothesis, according to which a chronic tendency of private investment to be insufficient to absorb private saving leads, in the absence of extraordinary policies, to extremely low interest rates, lower than desirable inflation and sluggish economic growth.

Much of the discussion has focused on movements in what has come to be called " $\mathrm{R}$ star"-Wicksell's neutral or natural interest rate at which investment fully absorbs saving at full employment. Estimating the level and change in the neutral real interest rate has become a cottage industry and the neutral real interest rates have come to play a prominent role in policy discussions.

Our main contribution in this paper is to recognize that the neutral real interest rate is not a deep structural feature of an economy but instead reflects both how it is embedded in the global economy and how fiscal policy is set. The neutral interest rate for an individual open economy will depend on its current account position which in turn depends on its real exchange rate which is itself a function of current and prospective real interest rates. It is therefore hard to interpret estimates of the neutral interest rate for a single open economy. We therefore estimate the neutral real rate for the industrial economies taken in aggregate. We show that our aggregate can to a good approximation be thought of as a closed economy. Our estimates suggest that the advanced economy neutral real rate has declined by about 300 basis points since 1980 and is now in the neighborhood of zero.

We emphasize that this substantial decline would have been substantially greater but for the buildup of government deficits and debt over the last generation and the increasing generosity of social insurance programs, particularly increases in old-age pensions. While the uncertainties inherent in any calculation are enormous, we estimate that, with constant fiscal and social insurance policies, neutral real interest rates would have declined by 700 basis points and would now be very substantially negative. Equivalently our estimate is that with constant real interest rates the gap between private saving and private investment rates in the industrialized world has widened by over 10 percent of GDP.

We make two methodological choices in this paper. We show that the current account balance of advanced economies taken as a whole has been small and stable over the past four decades, and, given that, we argue that it is preferable to view the advanced economies as a fully integrated bloc - a departure from the literature that tends to focus on individual countries when 
estimating neutral real rates. Second, we show that the dominant force driving the downward trend in real rates is common to a wide range of asset classes with differing characteristics. This explains the focus in the paper on forces driving the balance of desired saving and investment, as opposed to those that relate to liquidity or safety attributes of any particular asset class.

To set the scene we present the results from the econometric exercise estimating $\mathrm{R}^{*}$ for the industrialized world as a whole, which are that advanced economy neutral rate - what we call AE $R^{*}$ for brevity - has declined by around 300 basis points over the past half-century. This large decline in the relative price of consumption today vs. consumption tomorrow has meant that the observed saving and investment ratios remained broadly stable. In other words, the large decline in $\mathrm{R}^{*}$ had been a symptom of the excess saving problem, and has masked the underlying shifts in desired saving and investment propensities. To illustrate the magnitude of this problem, we calculate a counterfactual gap between saving and investment propensities under the hypothetical scenario of a constant interest rate. Our calculations suggest that, had interest rates not declined, the excess saving gap in advanced economies taken together would be very large - likely north of 10 percent of GDP. In the remainder of the paper we study the various factors that underlined this phenomenon.

Our main contribution is the analysis of public policies and their impact on $\mathrm{R}^{*}$. We show that all available evidence points to a sizeable positive influence: the secular trends in public policies in the industrialized world have helped to reduce the excess saving problem.

Policies may affect the interest rate through a range of channels. We review these mechanisms focusing on the role of government borrowing, which is the main focus of both theoretical and empirical literatures in macroeconomics. We then survey the existing empirical estimates of the impact of government debt on interest rates. Simple calculations using observed estimates of the impact of deficits on interest rates suggest that the increase from $18 \%$ to $68 \%$ in the public debt-to-GDP ratio of the advanced economies should ceteris paribus have raised real rates by between 1.5 and 2 percentage points over the last four decades. A similar calculation based on the existing empirical literature on the link between Social Security and private saving suggests that the 3 percentage points increase in Social Security spending-to-GDP may have increased interest rates by a further 50-100 basis points. Increasing old-age health expenditure likely have had a further positive impact. This analysis leads to the conclusion that the fall in real longterm interest rate observed in the data masks an even more dramatic decline in the equilibrium "private sector" real rate.

To build further understanding of the mechanisms involved and to cross-check the magnitudes of these effects, we study these phenomena in a dynamic general equilibrium framework. We construct two tractable models, each one designed to capture different channels through which policies play out in equilibrium. 
Building on the work of Mark Gertler (1999), the first model captures the life-cycle behavior, with workers saving for retirement and retirees decumulating their wealth. Ricardian equivalence - the proposition that government borrowing decisions are neutral in equilibrium - does not hold in our model, making the effects of a range of government policies on real rates nontrivial. Specifically, following a change in government finances, there is some Ricardian offset, but unlike in the representative agent model, this offset is incomplete. We simulate the model with the profiles of government debt, government spending, Social Security and old-age healthcare expenditures that match the experience of developed economies over the past 40 years. These simulations suggest that shifts in these policies pushed equilibrium real rates up by around 3 percentage points between the early 1970s and today.

Our second model focuses on individual risks and precautionary behavior, channels that are absent from the life-cycle model. When people cannot fully insure against future uncertainty surrounding their individual income, they value holding financial assets such as government debt for the purposes of self-insurance. This demand for assets is, in part, satisfied by governments issuing debt, and the more debt is issued, the lower is its price and the higher is the interest rate. Our numerical explorations suggest that the increase in the supply of government bonds has pushed interest rates up by about 40-70bps through this channel. Overall, then, we find that public policies may have pushed interest rates up by about 3.5 - 4 percentage points.

In the final Section of the paper we validate our models by using them to quantify the impact of some of the private sector forces that the existing literature suggested were important in driving the decline in the neutral real interest rates. Specifically, we show that the estimates of the impact of the decline in expected future growth, the demographic shifts, and the rise in income inequality on neutral real rates are well within the ranges of estimates found by other researchers. This lends credibility to the core contribution of our paper, namely the quantification of the boost that the public sector gave to neutral real rates in AEs.

The remainder of this paper is structured as follows. Section 2 discusses two methodological issues underlying our analysis. Section 3 contains the results of the estimation of the long-term equilibrium real interest rate for advanced economies. Section 4 starts with a discussion of the channels through which government policy influences the equilibrium rate; it then summarizes the results from the existing empirical literature which estimates the size of these effects; and finally it uses these elasticities to calculate some back-of-the-envelope measures of how policies affected $\mathrm{AE} \mathrm{R}^{*}$. In Section 5 we set up the two general equilibrium models and use them to study the impact of government policies. Section 6 validates the models by using them to assess the impact of secular demographic changes, slowdown in technology and the rise in inequality. Section 7 concludes. 


\section{Understanding Neutral Real Interest Rates}

We begin with a discussion of two methodological choices that permeate the analysis in this paper and where our approach differs from that of some other studies. The first is our treatment of advanced economies as a bloc rather than focusing on individual countries. The second is our view that the decline in neutral real interest rates can be understood through the balance between desired saving and investment. This view leads us to focus on the macroeconomic forces affecting a broad range of returns, rather than on factors driving spreads or premia on particular financial instruments, and to deemphasize the importance of "safe asset shortage" theories for understanding the broad low frequency movements in interest rates.

\subsection{Advanced economies as a bloc}

Our analysis assumes that the advanced economies bloc is fully integrated. In practice, we use aggregated data for all the developed countries (members of the OECD, whenever data are available), 'as if' the bloc was a single economic entity. We treat this bloc as a large, closed economy with perfect internal capital mobility.

The perfect internal capital mobility assumption is justified by very large gross and substantial net capital flows between developed economies, strong commonality in trends in longterm real rates observed in the data and high correlations in the performance of stock markets (Claessens and Kose, 2017).

The assumption that the industrial economies as a whole can be treated as a closed economy is justified by the observation that their aggregate current account balance has fluctuated by less than 1.5 percent of GDP over the last 40 years (Figure 1). Note also that the recent trend has been upward suggesting that international capital flows have if anything operated to raise interest rates over time.

More importantly, our approach avoids the erroneous assumption implicit in much of the country-level analysis that the economies under consideration are closed. Current account balances for individual economies are large and variable; they are endogenous outcomes of the saving and investment propensities within each economy relative to the global average. A country for example that runs a chronic trade surplus will be found to have a neutral real rate at a level where domestic demand is short of potential output and the reverse will be true for a country running a chronic trade deficit. External balances should therefore be taken into account in such country-level analyses. We instead posit that developed economies taken together experience structural excess saving, reflected in the trend-decline in real interest rates without a discernible trend in their current account. At this level of aggregation, the country-level differences washout, and econometric and theoretical analyses based on a closed-economy assumption are more 
credible.

Figure 1: Current account in advanced economy bloc and in selected individual economies

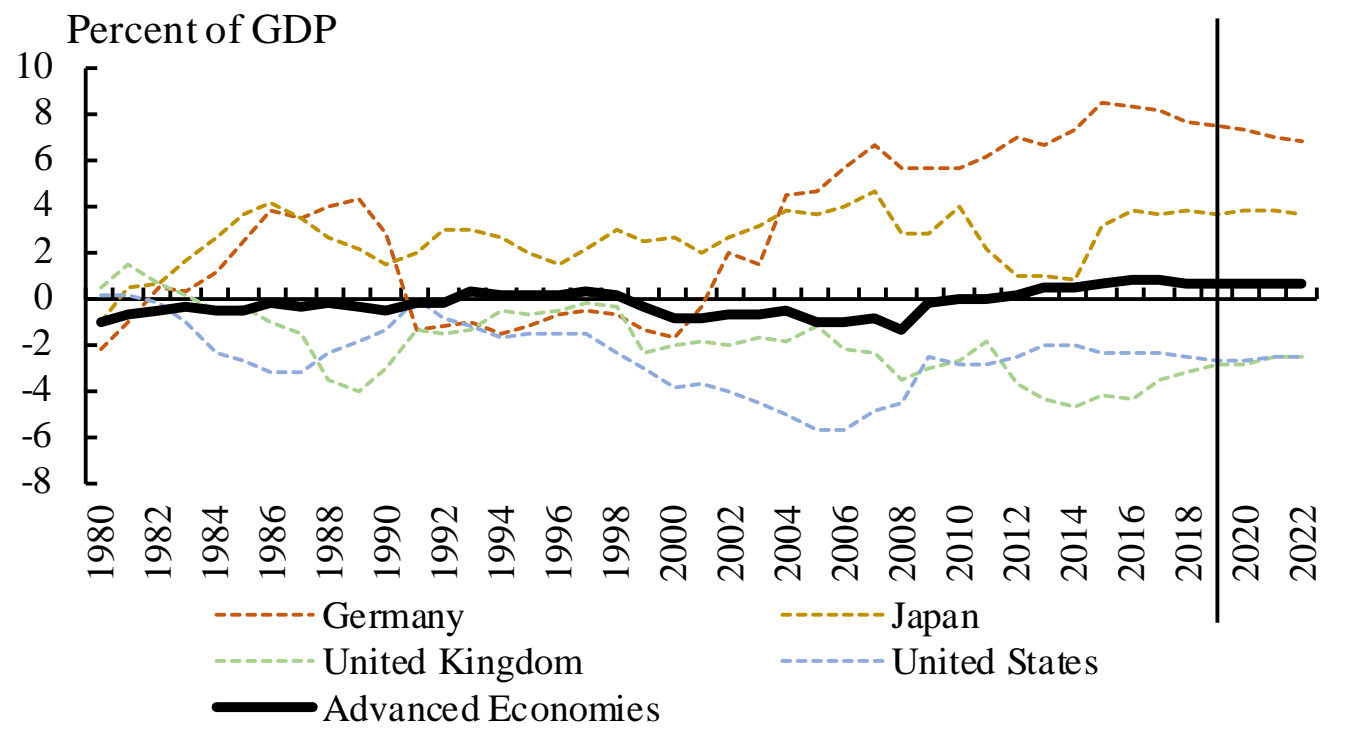

Note: The black line shows the current account for advanced economies as defined by the IMF.

\subsection{Excess of desired saving over investment, and the role of safety and liquidity premium}

We carry out our analysis on the basis of the premise that, for analyzing long-term trend movements in neutral real rates, it is appropriate to focus on factors relating to saving and investment propensities rather than issues of liquidity or risk. Consequently, our analysis abstracts from aggregate uncertainty and differing levels of liquidity of various assets.

Several facts support our approach. First, the decline in rates on highly liquid securities track declines in yields on relatively illiquid government indexed bonds and real swaps (Figure 2), suggesting that the liquidity characteristics of government bonds play only a secondary role. Second, even in the US, there has been little trend movement in spreads between Treasury securities and corporate securities in given rating classes, and while the pick-up in equity risk premia has been somewhat more pronounced, it is nonetheless small relative to the decline in real interest rates over the decades (the left panel in Figure 3). In any case, it is not clear whether one should interpret any changes in spreads as driven by changes in risk preferences or rather a result of changes in how risky the underlying assets are perceived to be. For instance, the recent global financial crisis has likely led to a reassessment of what it means that an asset is triple-A rated; while the dot-com bubble appears to have had a lasting impact on pricing of 
Figure 2: Real interest rates estimated from the inflation-linked bonds and forward swaps

(a) Real rates from TIPS

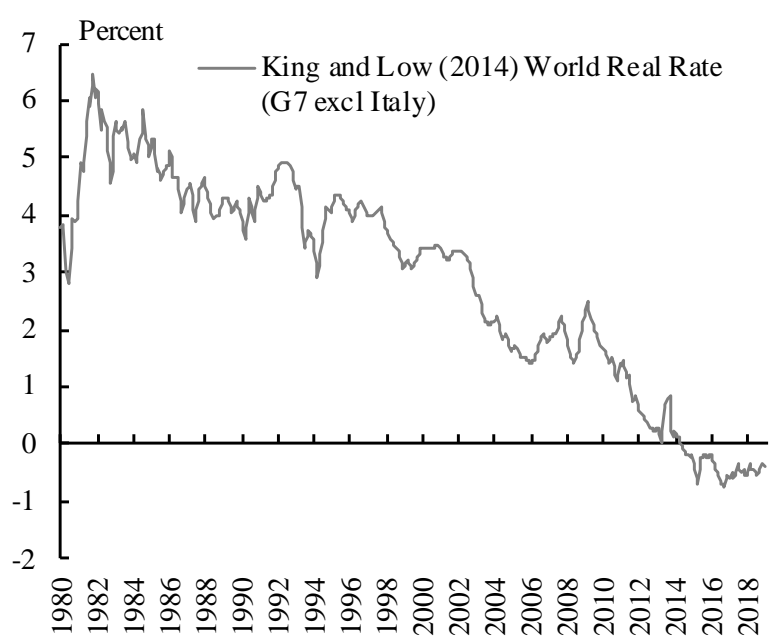

(b) Real 5-year/5-year forward swap rates

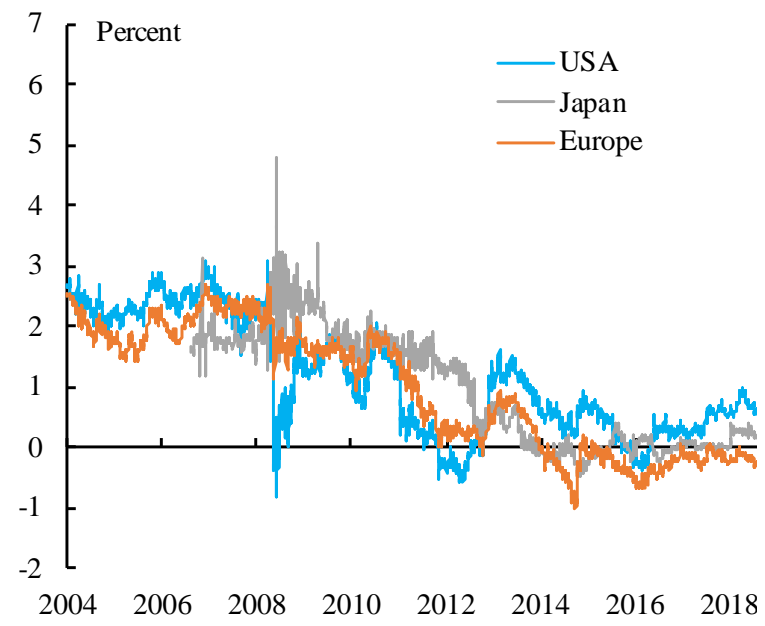

Notes: The world real rate is calculated following the methodology in King and Low (2014): it is the average of interest rates on inflation-protected government debt securities across the G7 excluding Italy. Data are from DataStream and form an unbalanced panel. In particular, the Figure relies on the UK inflation-indexed gilts in the early part of the sample. The US TIPS yield is the yield on a constant maturity 10-year Treasury Inflation-Indexed Security, retrieved from FRED, Federal Reserve Bank of St. Louis (code DFII10). Swaps data are from Bloomberg.

equities.

To get a sense of the relative importance of the trend decline in real returns versus changes in the dispersion between them, we summarize the patterns in the US data using principal components. Principal components analysis (PCA) is a statistical procedure that summarizes the information in the correlated data series with a smaller set of mutually uncorrelated variables. The components are ordered in such a way that the first explains the highest share of variance in the data. The PCA thus offers a way of quantitatively distinguishing between the excess saving story which drives the common trend across all real rates, and the safety and liquidity story which drives the dispersion between them.

When we perform this analysis on the set of US real yields that span government debt, corporate bond and equity markets, we obtain results that are telling: the first principal component, which picks up the downward trend visible in all returns, explains $94 \%$ of the total variance in the underlying series (Panel B in Figure 3). The second principal component, which appears to be related to the increase in the "convenience yield", explains only $5 \%$. The very large share of total variance in the data accounted for by the common downward trend supports our focus in this paper.

This focus is also consistent with the finance literature that investigates the decline in the neutral real interest rates in presence of term and liquidity premia ((Christensen and Rudebusch, 
Figure 3: Real returns in the United States: data and principal components
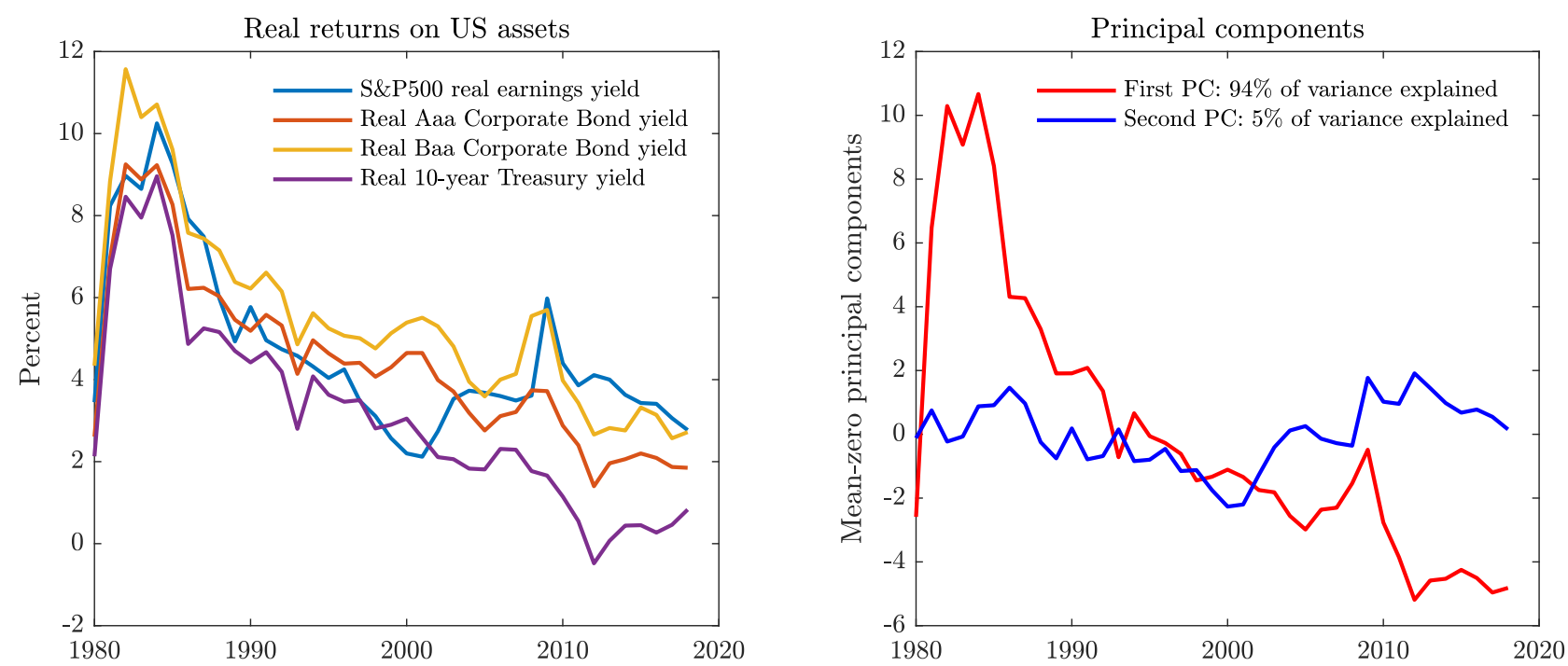

Source: FRED, Robert Shiller and author's calculations.

Notes: 10 year Treasury real yield post-2004 is the yield on 10-Year Treasury Inflation-Indexed Security (code: DFII10). Before 2004 it is the nominal yield (GS10) minus inflation expectations measure from the Michigan survey (code: $\mathrm{MICH}$ ). The real corporate yields are nominal yields (codes: AAA, BAA) minus inflation expectations from TIPS (post-2004) or from Michigan survey (pre-2004). Real earnings yield is the inverse of the cyclically adjusted total return price real earnings ratio from Robert Shiller (available at http://www.econ.yale.edu/ shiller/data.htm).

2017), D'Amico et al. (2018)). The "safe asset" literature finds somewhat larger role for the convenience yield, but even there the magnitudes are generally rather small relative to the large trend decline in real rates. For example, using very different approaches, Del Negro et al. (2018) and Rachel and Smith (2017) concluded that the rise in the spread between risky and risk-free rates accounted for about $70 \mathrm{bps}$ of the decline in risk-free rates. This is less than a quarter of the overall decline in real neutral rates since 1980.

In summary, much of the available evidence points to a common underlying decline in real interest rates across different financial assets. This suggests that saving and investment propensities and how they changed over time is the dominant underlying driver of such trend.

\section{Estimating the AE equilibrium real interest rate}

We estimate the natural rate of interest for advanced economies adopting what is perhaps the most celebrated applied empirical model designed for this purpose, originally due to Laubach and Williams (2003) (LW) and recently re-applied internationally by Holston et al. (2017b). Conceptually, this approach draws on two strands on the literature. By following Wicksell's (1989) definition of the natural rate as the rate consistent with stable inflation and output 
remaining at equilibrium ("potential") level, it is well aligned with the modern monetary theory, as in Walsh (1998), Woodford (2003) and Gali (2008). That literature is primarily concerned with fluctuations at the business-cycle frequency, where shocks move the economy around a stable steady state. In addition to those business-cycle shocks, the framework employed here is flexible enough to capture secular forces that affect the steady state.

\subsection{Sketch of the model and the estimation procedure}

Our approach to estimating the LW model is deliberately off-the-shelf: we use exactly the same procedures as the recent papers in that literature. Out contribution is solely to perform this exercise on the bloc of advanced economies as a whole. As such, we do not take a stance on the performance of the model, although we discuss some of the issues below.

The philosophy of the LW method is that the natural rate of interest is an endogenous object determined in general equilibrium, and as such it will depend on a host of socio-economic forces, such as trends in preferences, technology, demography, policies and policy frameworks, and so on. It is impossible to know and measure all of the relevant factors. At the same time, a robust prediction of most workhorse macroeconomic models is that the natural rate should vary together with the (expected future) trend growth rate of the economy. ${ }^{1}$ To reflect the dependence on growth and on a range of (possibly unknown) other factors, the LW model assumes that the natural rate, denoted $r_{t}^{*}$, depends on the estimated trend growth rate of potential output $g_{t}$ and a time-varying unobserved component $z_{t}$ that captures the effects of other unspecified influences:

$$
r_{t}^{*}=g_{t}+z_{t}
$$

The model further assumes that both the growth rate $g_{t}$ and the unobserved component $z_{t}$ are random walk processes:

$$
\begin{array}{ll}
g_{t}=g_{t-1}+\epsilon_{g, t} & \epsilon_{g} \sim N\left(0, \sigma_{g}^{2}\right) \\
z_{t}=z_{t-1}+\epsilon_{z, t} & \epsilon_{z} \sim N\left(0, \sigma_{z}^{2}\right)
\end{array}
$$

The model specification also admits shocks to the level of potential output. Denoting by $y_{t}^{*}$ the natural logarithm of potential output at time $t$ :

$$
y_{t}^{*}=y_{t-1}^{*}+g_{t-1}+\epsilon_{y^{*}, t} \quad \epsilon_{y^{*}} \sim N\left(0, \sigma_{y^{*}}^{2}\right)
$$

In short, the LW model views the natural rate as the sum of two independent random walks.

\footnotetext{
${ }^{1}$ We discuss the rationale for this link in some detail in Section 5.
} 
To achieve identification, LW add two further equations to the model. First, they specify a simple reduced-form equation relating output gap to its own lags, a moving average of the lagged real funds rate gap, and a serially uncorrelated error:

$$
y_{t}=y_{t}^{*}+a_{1}\left(y_{t-1}-y_{t-1}^{*}\right)+a_{2}\left(y_{t-2}-y_{t-2}^{*}\right)+\frac{a_{r}}{2} \sum_{j=1}^{2}\left(r_{t-j}-r_{t-j}^{*}\right)+\epsilon_{y, t} \quad \epsilon_{y} \sim N\left(0, \sigma_{y}^{2}\right)
$$

The key in this estimated IS relation is the $a_{r}$ coefficient, which we expect to be negative. Second, LW add the reduced-form Phillips curve to the model, linking current inflation $\pi_{t}$ to lagged inflation and the output gap:

$$
\pi_{t}=b_{\pi} \pi_{t-1}+\left(1-b_{\pi}\right) \pi_{t-2,4}+b_{y}\left(y_{t-1}-y_{t-1}^{*}\right)+\epsilon_{\pi, t} \quad \epsilon_{\pi} \sim N\left(0, \sigma_{\pi}^{2}\right)
$$

where the standard theory would suggest that coefficient $b_{y}$ is positive.

The system above can be written in a state-space form, and the Kalman Filter can be used to estimate the unobservable states. To estimate the model, we use data for advanced economies as a bloc. The data comprise of (log) quarterly real GDP, core inflation and long-term interest rates over 1971Q1:2017Q4 for the aggregated sample of OECD countries. The interest rate series is the average of long-term nominal interest rates across an unbalanced panel of 36 OECD economies. ${ }^{2}$ To calculate real rates, we subtract from nominal rates a simple measure of expected inflation, constructed as the moving average of past core inflation rates, in line with Holston et al. (2017b). See online Appendix A for further details on the data and the estimation procedure.

\subsection{Results}

Table 1 shows the coefficients of the estimated model. Point estimates are all significantly different from zero and have expected signs. In particular, a positive interest rate gap reduces the output gap, while a positive output gap raises inflation. Table 1 also shows the standard errors around the estimated trends, which are large, especially those around the estimates of equilibrium real rate. These wide standard error bands are not specific to our results - indeed, they are a norm in the literature. For instance, Holston et al. (2017b) report similarly large errors for individual economies. These errors are, to an extent, an artifact of the long-sample, as they reflect the cumulative uncertainty of the underlying drivers of equilibrium rates. Nonetheless, these large error bands should act as a reminder of the high uncertainty surrounding the econometric estimates of equilibrium interest rates.

Figure 4 contains the key results. According to our estimates, AE $\mathrm{R}^{*}$ declined steadily from

\footnotetext{
${ }^{2}$ The results are robust to using weighted average or median of the interest rates across countries. Given the strong comovement, these interest rate series are close to each other.
} 
Table 1: State-space model parameter estimates

\begin{tabular}{cccccccc}
\hline \multicolumn{8}{c}{ Parameter point estimates (t-statistics in parentheses) } \\
$a_{1}$ & $a_{2}$ & $a_{r}$ & $b_{\pi}$ & $b_{y}$ & $\sigma_{y}$ & $\sigma_{g}$ & $\sigma_{z}$ \\
1.71 & -0.79 & -0.04 & 0.90 & 0.09 & 0.25 & 1.03 & 0.31 \\
$(21.65)$ & $(10.28)$ & $(2.13)$ & $(17.78)$ & $(2.06)$ & $(5.30)$ & $(29.63)$ & $(9.38)$ \\
\multicolumn{8}{c}{ Average standard errors around the estimates } \\
$y *$ & $r *$ & $g$ \\
& 1.19 & 3.12 & 0.16 & \\
\hline
\end{tabular}

Figure 4: AEs $\mathrm{R}^{*}$ and trend growth

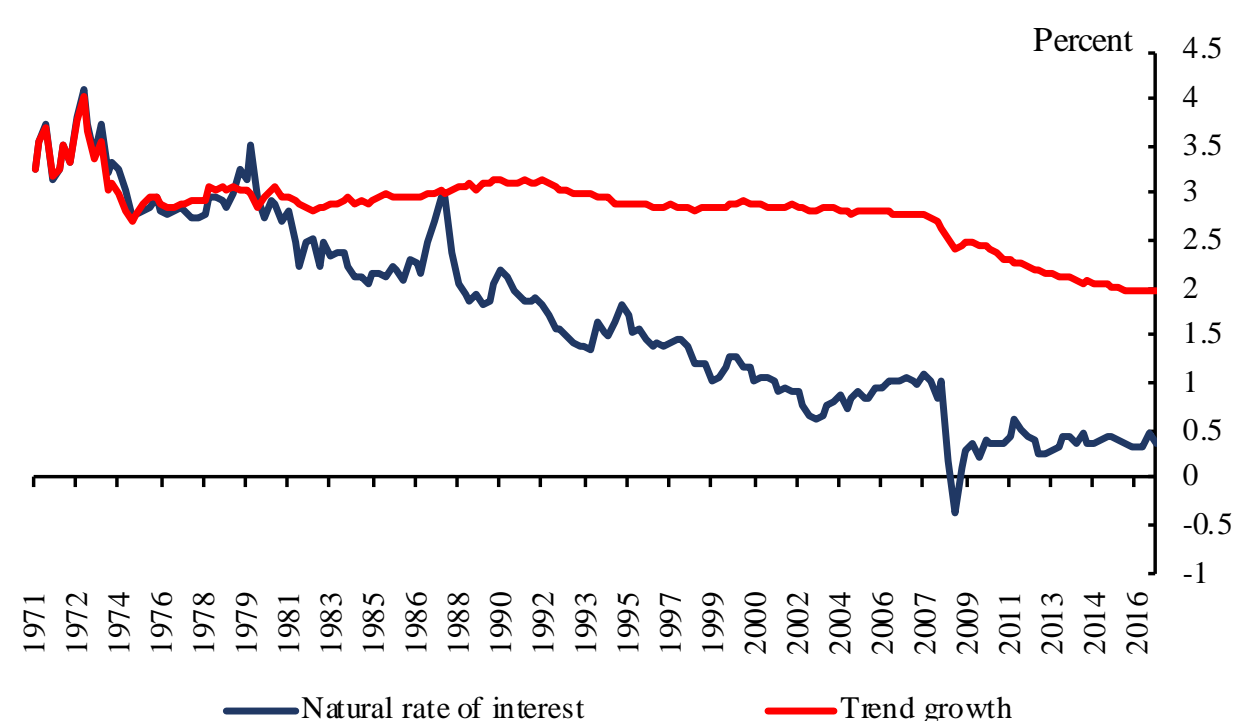

1980 s onwards, and fell sharply during the crisis. ${ }^{3}$ It then stabilized at low levels $(\approx 0.5 \%)$. The estimated growth rate of potential output has been broadly stable up until the crisis, and declined during the crisis by about 1pp. Thus the model suggests that a bulk of the decline in real interest rates is due to factors other than trend GDP growth. This is consistent with the literature that finds only a loose connection between actual GDP growth and interest rates in historical data (Hamilton et al. (2016)).

These results corroborate other existing findings in the literature. In particular, Holston et al. (2017b) estimated that the declines in real rates for US, Canada, Euro Area and the UK of around 2.3pp between 1990 and 2017; for comparison, the decline over this period for AEs as a whole that we estimate here is around 2pp.

Overall, despite large uncertainty surrounding the point-estimates of these trends, we interpret the results of this exercise as broadly in line with the country-level findings in the literature.

\footnotetext{
${ }^{3}$ Estimates for the first decade should be taken with a grain of salt, as the model is less accurate during the first few years of the sample while the initial conditions play a larger role.
} 
Indeed, given the high level of aggregation, we find it encouraging that the estimated unobservables do well at picking up the main events, such as the global financial crisis, during which our estimate of $\mathrm{AE} \mathrm{R}^{*}$ declines very sharply.

Perhaps more significantly our estimates of the decline in the neutral real rate track the evolution of 10 year real yields depicted in Figure 2. This both provides further corroboration of our estimates and suggests a market judgement that real rates are likely to remain low for the foreseeable future.

\subsection{The fall in $\mathrm{AE} \mathrm{R}^{*}$ and the excess saving problem}

The decline in the neutral real rate of this magnitude is a symptom of deep, fundamental changes that have taken place in the developed economies over the last half-century. A useful way to think about these trends is through the lens of desired saving and investment, with the desire to save running ahead of the desire to invest. However, illustrating the fundamental change in this space is not straightforward, because the large fall in the intertemporal price - the interest rate - meant that the observed saving and investment ratios remained broadly stable throughout this period. The left panel of Figure 5 shows the realized PPP-weighted private savings and investment ratios in the OECD, in proportion to the aggregate OECD GDP. The saving ratio is almost completely stable, and while there is some movement in the private investment-to-GDP, there certainly is no strong trend.

To assess the magnitude of the forces that operated under the surface in terms of excess saving over investment, one needs to perform a counterfactual analysis. Here we present a simple but telling attempt. Specifically, we calculate the counterfactual difference between private sector saving and investment - the counterfactual private sector savings-investment gap - under an assumption of no decrease in the interest rate since the 1980s. To construct such counterfactual, we need an estimate of the strength of the link between desired saving and investment and the interest rate. We rely on the estimates reported in empirical literature (see Rachel and Smith (2015) for a review) which suggest that the elasticity of desired saving is in the region of 0.30.7 and the elasticity of desired investment is around -0.5 to -0.7 . With average saving- and investment-to-GDP at around $20 \%$, these elasticities imply that a 1 percentage point decline in real interest rate is associated with a widening of the saving-investment gap of between 2 and 4 percentage points, with central view of the sensitivity of around 3. Given the uncertainties, we report the counterfactual gap under this range of sensitivities.

The main message from these simple calculations is striking: absent the cushioning decline of the interest rate, the excess saving gap would have been very large. The right panel of Figure 5 indicates that it would have been between 9 and 14 percentage points.

Motivated by the size of these movements we now turn to the discussion and analysis of the 
forces behind them. Our contribution is the focus on the role that public policies have played over this period.

Figure 5: Private saving and private investment: the level and gap

(a) Private saving and private investment

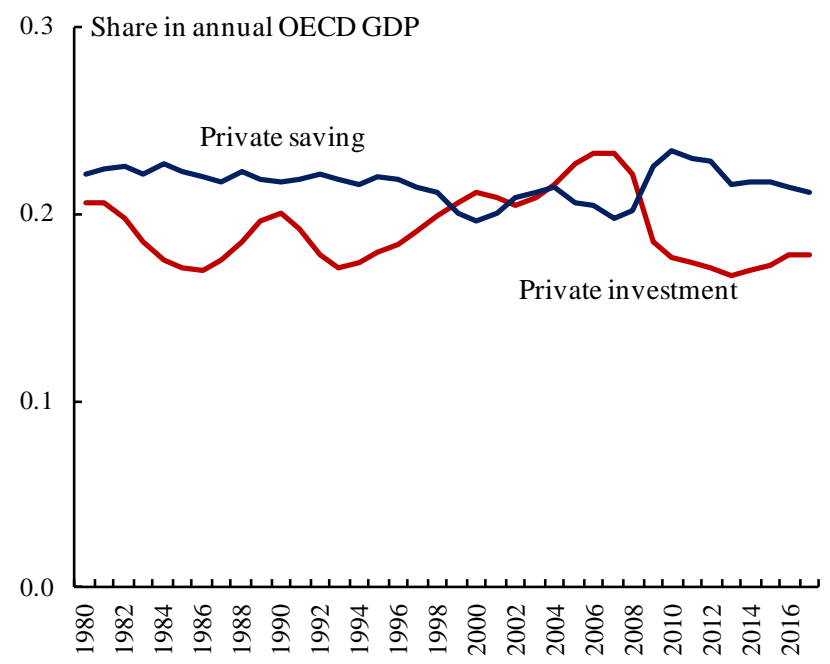

(b) Excess saving gap

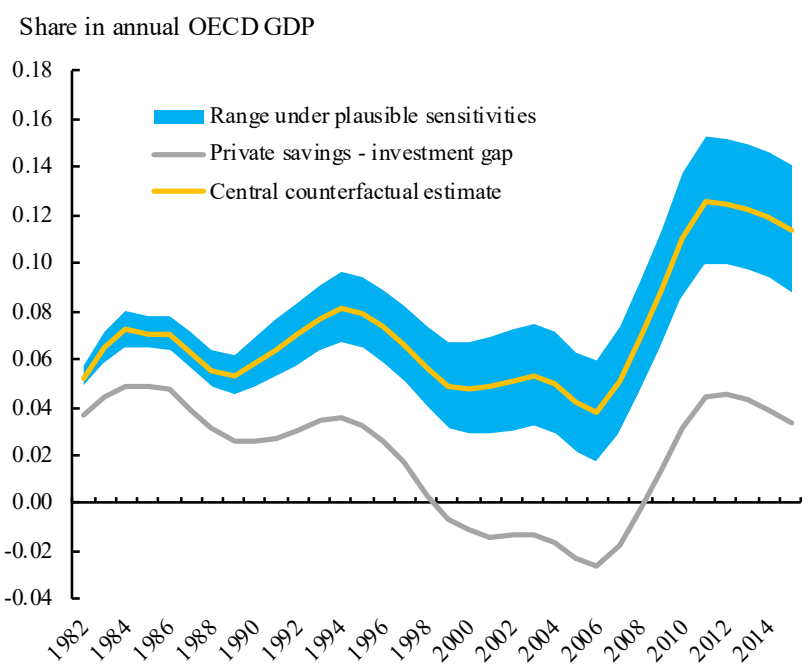

Source: IMF, OECD and authors' calculations.

Notes: The figure in the left panel shows PPP-weighted gross private saving and gross private fixed capital formation across the following countries: Australia, Austria, Belgium, Canada, Czech Republic, Denmark, Estonia, Finland, France, Germany, Greece, Iceland, Ireland, Israel, Italy, Japan, Korea, Latvia, Lithuania, Luxembourg, Netherlands, New Zealand, Norway, Portugal, Slovakia, Slovenia, Spain, Sweden, Switzerland, United Kingdom, United States. The figure on the right shows the result of a simple counterfactual exercise where we calculate the private savings-investment gap under a scenario of no decline in the long-term interest rate since the 1980s. The swathe contains the counterfactual for values of responsiveness of S/I ratios to interest rates between 2 and 4 , and the central counterfactual estimate assumes the sensitivity of 3.

\section{Government policy and the equilibrium interest rate}

Over the past several decades, government policy in the developed world has shifted significantly in at least four respects (Figure 6). First, government debt has risen, from around 20\% of GDP to around $70 \%$ (government consumption - excluding healthcare - remained relatively stable). Second, old-age payments administered through the social-security and healthcare systems have gone up, from $4 \%$ to $7 \%$ and from $2 \%$ to $5 \%$ of GDP, respectively, accounting for the lion share of the increase in total social spending (Figure 7). Third, significant changes to tax policies have taken place. The effective corporate tax rates in the rich economies have fallen, from around $32 \%$ at the turn of the century to $24 \%$ more recently. ${ }^{4}$ Wealth taxes, operational in 12 OECD countries in 1990, remain in place only in 4 counties today (OECD (2018)). And, as documented

\footnotetext{
${ }^{4}$ See http://www.oecd.org/tax/tax-policy/fig7-avg-statutory-tax-rates-by-region-large.png for details.
} 
by Thomas Piketty and Emmanuel Saez (2007), the overall progressivity of the tax system has decreased in some jurisdictions - notably in the United States and the United Kingdom.

These shifts are likely to have had a profound impact on the economy in general, and on the equilibrium rate of interest in particular. Specifically, all of these shifts - perhaps with the exception of tax changes - are likely to have pushed interest rates higher over the past 30 years. In this and the next section we turn to the analysis of the impact of these policy shifts on the natural rate, with the ultimate goal to inform the counterfactual 'pure' $\mathrm{R}^{*}$ that would prevail without government intervention.

We focus on government debt, Social Security and healthcare spending, leaving the formal analysis of the impact of tax changes for future work. We find that shifts in government policy have likely pushed equilibrium rates of interest up by a significant amount over the period in question. As a rough rule of thumb on the magnitudes involved, our analysis suggests that the tripling of the government debt over the past half century raised rates by 1.5 percentage points, while the expansion of social spending of around 5\% of GDP added a further 2.5 percentage points. While the precise magnitudes of these multipliers are subject to substantial model and statistical uncertainty, the qualitative conclusion is clear: had the public policy not responded, the advanced world's equilibrium rate would likely be deeply negative. ${ }^{5}$

\subsection{A brief review of the theoretical arguments}

We begin by reviewing the effects of government policy on the equilibrium interest rate, focusing on government borrowing, as this has been the main subject of the large literature in macroeconomics which we can draw on. ${ }^{6}$

In the canonical neoclassical model with complete markets and infinitely-lived agents, Ricardian Equivalence holds and neither deficit nor debt are relevant, as the representative household can fully offset the changes to government's borrowing policy through its saving decisions. Thus independent shocks to government borrowing alone have no effect on the equilibrium interest rate. The neoclassical model instead emphasizes the link between the stock of capital and the interest rate: in equilibrium $r=f^{\prime}(k)-\delta .{ }^{7}$ Thus government policies affect the interest rate

\footnotetext{
${ }^{5} \mathrm{~A}$ corollary of this link between government debt and interest rates is that a higher value of public debt, compared to market expectations, is likely to raise the natural interest rates. For analysis of this argument, see Kocherlakota (2015).

${ }^{6}$ In our work we do not explicitly model the impact of quantitative easing (QE) policies. One kind of QE encompasses policies that swap risky assets for safe assets and includes QE1 in the US or the LTRO in the Eurozone. Such policy may raise the short-run rate ((Caballero and Farhi, 2018)), whereas we focus on the long-run rate. Another kind is a policy whereby the central bank issues reserves to buy risk-free debt. Such policy is primarily a maturity transformation of government debt, rather than change in the total availability of investable assets.

${ }^{7}$ On the balanced growth path, the level of effective capital stock adjusts such that the interest rate simultaneously satisfies the balanced growth version of the representative household's Euler Equation: $r=\frac{1}{I E S} \cdot g+\theta$
} 
Figure 6: Advanced economies government policy ratios (in proportion to GDP)

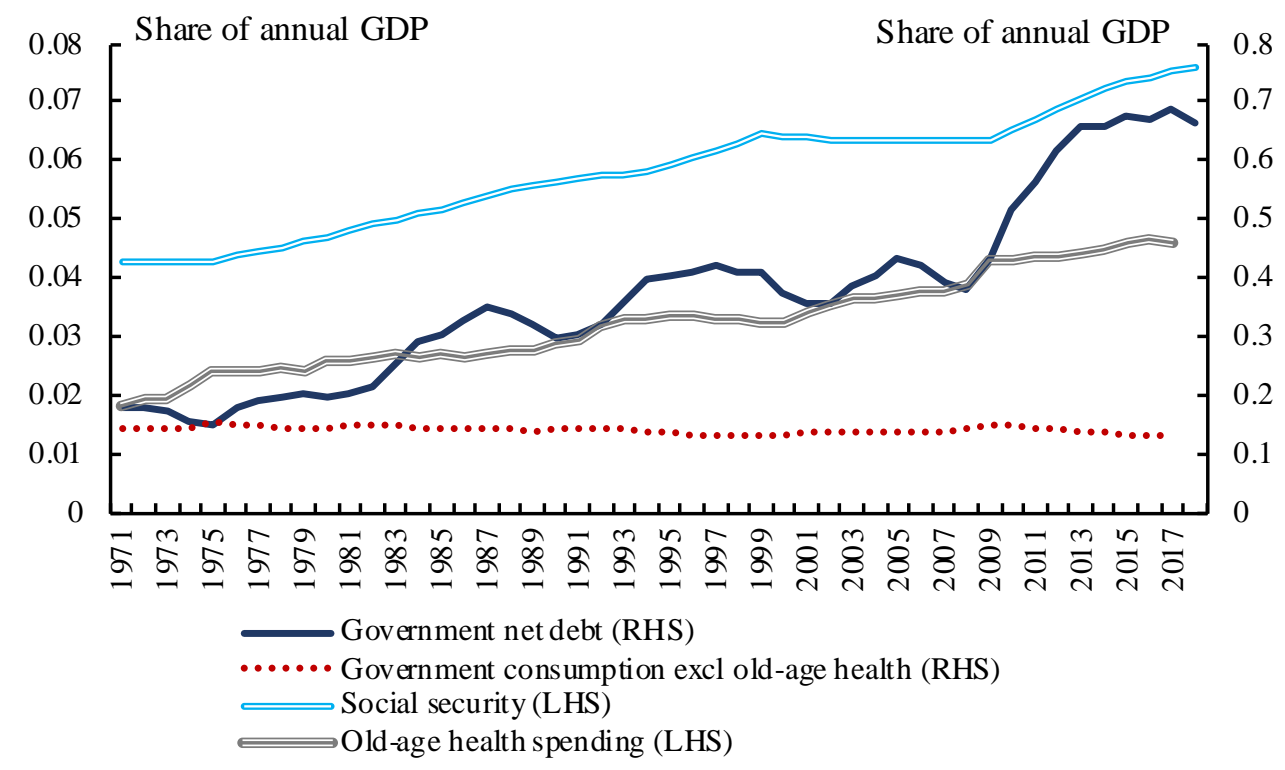

Notes: The Figure shows OECD aggregates in proportion to total OECD GDP. All data are from the OECD. Government net debt line measures the general government net financial liabilities, from the OECD Economic Outlook Database. It includes net government debt held by the public and also other net liabilities of the government. For example, in the United States in 2017, the net financial liabilities as reported by the OECD were $80 \%$ of GDP, while net debt held by the public was $75 \%$ of GDP. Government consumption figures represent the general government final consumption expenditure, adjusted by subtracting the old-age health spending (note that this series excludes the Social Security transfers by default). The old-age health spending is calculated as the aggregate health spending on ages $65+$. The overall health spending figures are from the OECD/WHO statistics on sources of funding for healthcare. They include healthcare financed directly by the government and from the compulsory schemes. The old-age share is then calculated under the assumption that $60 \%$ of total health spending is directed at the older demographic groups, consistent with the evidence available for a handful of OECD countries.

only to the extent that they impact on the stock of private capital.

However, in the micro-founded modern macroeconomic models that depart from the representative agent and complete markets assumptions, Ricardian Equivalence does not hold, and government transfer policies affect the equilibrium allocations through several distinct channels.

First, the intertemporal transfers - that is, redistribution across time - matters if peoples' planning horizons are finite. This could be because of finite lives coupled with less-than-perfect bequest motive, as in the seminal models of Peter Diamond (1965) and Olivier Blanchard (1985), or perhaps due to time-dependent preferences and myopic behavior pioneered by David Laibson (1997). The reason is intuitive: with finite planning horizon, agents currently alive expect to shoulder only a part of the financing burden that comes with today's transfer; the rest is to be serviced by future generations. Such transfers thus affect agents' wealth and their consumption and saving plans.

where IES is the intertemporal elasticity of substitution and $\theta$ is the rate of time preference. 
Figure 7: Public social spending in the OECD

25 Percent of GDP

$m$ Old age

morvivors

Incapacity related

moxx Health

-. Family

Active labour market programmes

Unemployment

Housing

Other social policy areas

20

- Total

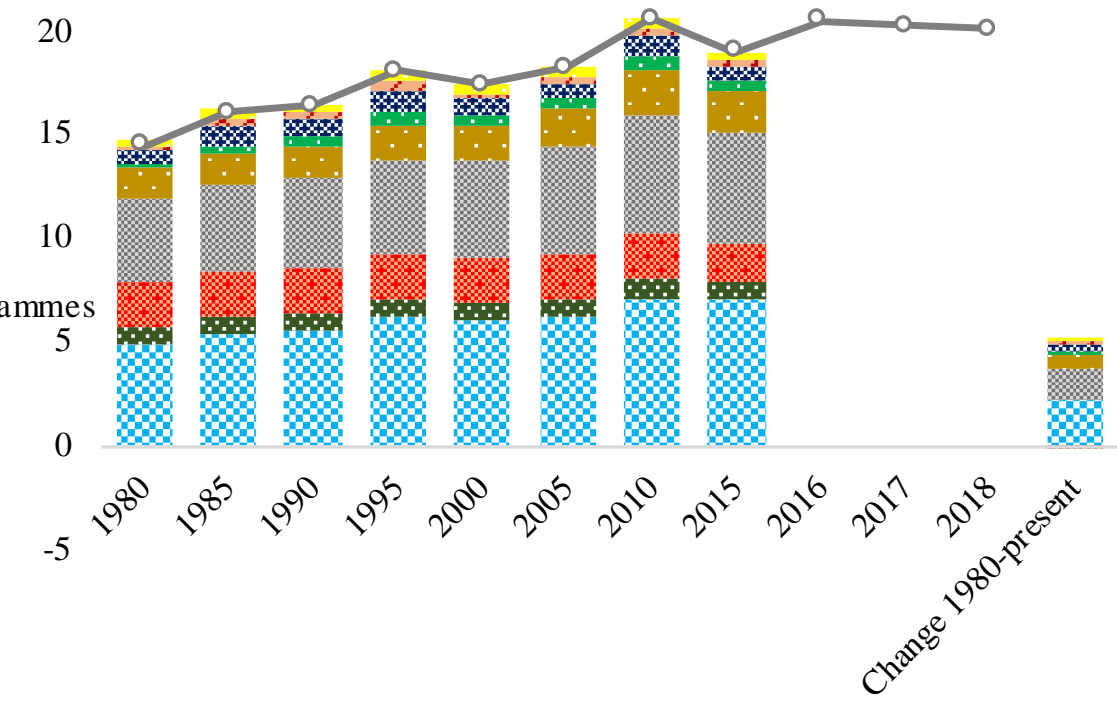

Notes: Data are from the OECD Social Expenditure Database (SOCX). The data for 2016-2018 are preliminary and the breakdown by function is not yet available.

Second, transfers across agents can affect aggregate consumption and saving (and hence the interest rate) if agents have different marginal propensities to consume (MPCs). Differences in MPCs could arise because of several distinct features of the economic environment. They could be a result of uninsurable risks and binding borrowing constraints, as in the works of Rao Aiyagari and Ellen McGrattan $(1993,1998)$ and the model of Hyunseung Oh and Ricardo Reis (2012). They could emerge because some agents have little to no liquid wealth, preventing them from adjusting their consumption, as in the paper by Greg Kaplan, Giovanni Violante and Justin Weidner (2014). Another reason may be the life-cycle: propensity to consume may differs between workers and retirees, as in Gertler (1999), or may vary with age as in Gagnon et al. (2016) and Eggertsson et al. (2019). Heterogenous MPCs and distortionary taxes deliver this result in the savers-spenders model of Gregory Mankiw (2000). ${ }^{8}$ In all those models, government transfers from a low-MPC agent to a high-MPC agent will boost the aggregate desire to consume and lower desired savings, thereby raising the interest rate.

The third way in which government policy affects interest rates is what may be called a precautionary saving channel. One facet of this channel is that government policies can directly reduce the risks faced by the agents. The mechanism is close to the one analyzed by Engen and Gruber (2001). Under imperfect insurance, agents who face some idiosyncratic risks -

\footnotetext{
${ }^{8}$ In the savers-spenders model of Mankiw (2000), if taxes are levied lump-sum, a deficit-financed transfer that permanently increases the level of debt does not affect the stock of capital or the interest rate in the long run. The reason is that the interest rate is pinned down by the savers, who are infinitely lived and Ricardian.
} 
for example those related to health or unemployment - attempt to self-insure through saving. This precautionary saving motive acts to push the interest rate below the rate that would prevail in a complete markets economy (where all risks are insurable and so do not affect the agents' behavior). Government policies such as social insurance will affect the importance of precautionary saving: a stronger social safety net or higher unemployment and disability benefits curtail the associated risks, curbing the desire to save. Conversely, lack of social insurance means that agents need to rely on their own resources when experiencing hardship, making personal saving a priority. However, as illustrated in Figure 7, the overall size of the social safety net across the OECD has changed little over the period in question. We do not attempt to model it here, but leave it as an important direction to be explored in future work.

The other facet of the precautionary saving channel - and the one we focus on in this paper works through the provision of assets which agents use to insure themselves against shocks. This mechanism is at the heart of Aiyagari and McGrattan (1998) and has recently been discussed in the context of secular stagnation in Caballero et al. (2016) and Caballero and Farhi (2014). The intuition we have in mind is simple: a rise in government debt raises the overall supply of assets in the economy, which, all else equal, pushes interest rates up. Indeed, there is evidence in the data that government debt constitutes a non-trivial proportion of the total investable financial assets in the developed world, so that this channel can have a quantitative bite. The estimates of the share of government bonds in total financial assets range from one-third in the US to two-thirds in Japan (Kay (2015)).

In summary, macroeconomic theory developed over the past couple of decades enriched the basic model of Frank Ramsey and Robert Barro (Barro (1974)) with several channels that make the government policy a relevant determinant of the long-term interest rate. We now turn to the empirical evidence that has been accumulated in parallel to these theoretical advances.

\subsection{Empirical evidence on the link between government debt and long-term interest rates}

The main challenge when estimating the effect of government borrowing on interest rates is the

large number of potentially confounding factors which may make simple regressions of interest rates on debt spurious and uninformative. For example, deficits will tend to expand when the economy weakens, which is also the time when interest rates tend to fall. This means that the simple regression coefficients are likely to be biased downward.

We shall not attempt a full-blown empirical assessment in this paper, and instead present a summary of the empirical estimates in the literature. For an interested reader, online Appendix B illustrates several challenges of estimating the causal relationship between equilibrium interest 
rates and government debt through a simple empirical exercise for the US, Canada, Euro Area and the UK. These challenges include the presence of international capital flows and of endogenous responsiveness of policy to excess of private saving over private investment, both of which are likely to attenuate the individual-country estimates of the impact of deficits on interest rates. Instead, we present the estimates from a broad literature that attempted to deal with these and other confounding factors in finding the link between government finances and real rates.

Several key studies in the empirical literature focused on the United States. In a chapter of the Handbook of Macroeconomics at the turn of the century, Douglas Elmendorf and Gregory Mankiw (1999) reviewed the theoretical and empirical literature on the Ricardian Equivalence proposition, concluding that, while the studies that attempted to estimate the impact of government finances on interest rates cannot reject the null hypothesis of zero impact, they suffer from lack of statistical power. ${ }^{9}$ More recent work appears more conclusive. In their literature review of this topic, William Gale and Peter Orszag (2002) conclude that the effect of government deficit on the real rates is positive and economically significant: a 1pp increase in the deficit-to-GDP ratio tends to raise interest rates by around 50-100bps. And the two most authoritative contributions on the topic suggest estimates that are significant, albeit somewhat smaller. Thomas Laubach (2009) studies how forward rates on government securities react to news in CBO's fiscal forecasts. The identifying assumption in his work is that long-term rates and forecasts are not contaminated by current events and shocks at the business cycle frequency. According to his estimates, a rise in government deficit of 1pp of GDP raises interest rates by about 20-30bps; an equal increase in debt/GDP ratio results in a rise of about 3-4bps. He asserts that these flow- and stock-multipliers are broadly consistent, because of the autocorrelation of the deficits observed in the data. ${ }^{10}$ Another important contribution to this literature is that of Eric Engen and Glenn Hubbard (2004), who consider a host of specifications linking interest rates or changes in interest rates to government debt or to the deficit, both contemporaneously and in a forward looking setting. Their results suggest that a 1pp rise in government debt / GDP pushes interest rates up by about 3bp, broadly in line with Laubach's findings. ${ }^{11}$

Further evidence is available for advanced economies beyond the United States. In an international setting, Anne-Marie Brook (2003) documents that the range of estimates of the effect of a 1 pp increase in government debt/GDP ratio on interest rates is 1-6bps, with the corresponding

\footnotetext{
${ }^{9}$ They write of the literature that tends to find close to zero effect of government deficit on rates: "Our view is that this literature [...] is ultimately not very informative. [...] Plosser (1987) and Evans (1987) generally cannot reject the hypothesis that government spending, budget deficits, and monetary policy each have no effect on interest rates. Plosser (1987) also reports that expected inflation has no significant effect on nominal interest rates. These findings suggest that this framework has little power to measure the true effects of policy."

${ }^{10}$ Specifically, he estimates the autocorrelation of 0.83 , implying that the $1 \mathrm{pp}$ rise in the deficit should have $\frac{1}{1-0.83}=6$ times the effect of a $1 \mathrm{pp}$ rise in debt - broadly in line with what he finds.

${ }^{11}$ The results vary across different specifications, highlighting that the precise econometric details matter for the conclusions of this line of empirical research.
} 
Table 2: Impact of government borrowing on the interest rate: summary of the literature

\begin{tabular}{lccc}
\hline \multicolumn{1}{c}{ Study } & Country / region & $\begin{array}{c}\text { 1pp increase } \\
\text { in deficit/GDP }\end{array}$ & $\begin{array}{c}\text { 1pp increase } \\
\text { in debt/GDP }\end{array}$ \\
\hline Gale and Orszag (2002) & US & $50-100 \mathrm{bps}$ & - \\
Laubach (2009) & $\mathrm{US}$ & $20-30 \mathrm{bps}$ & $3-4 \mathrm{bps}$ \\
Engen and Hubbard (2004) & $\mathrm{US}$ & $18 \mathrm{bps}$ & $3 \mathrm{bps}$ \\
FRB/US model & $\mathrm{US}$ & $40-50 \mathrm{bps}$ & - \\
Faini (2006) & Euro Area & $40 \mathrm{bps}$ & - \\
Brook (2003) & Advanced economies & $20-40 \mathrm{bps}$ & $1-6 \mathrm{bps}$ \\
Kinoshita (2006) & 19 OECD economies & - & $4-5 \mathrm{bps}$ \\
\hline Average & & $38 b p s$ & $3.5 \mathrm{bps}$ \\
\hline
\end{tabular}

range for a $1 \mathrm{pp}$ increase in deficits in the region of 20-40 basis points. In an important study of the Euro Area, Riccardo Faini (2006) finds that a 1pp rise in deficits at the Euro Area level raises long-term rates by around 40bps, close to - and if anything, higher than - the US multipliers. Considering an even wider panel of 19 OECD economies spanning 1971-2004, Noriaki Kinoshita (2006) finds that the effect of a $1 \mathrm{pp}$ rise in government debt-to-GDP ratio is to raise interest rates by $4-5 b p s$.

A complementary way to assess the size of these effects is to consider simulations from largescale models used for quantitative analysis in policy institutions. Because these models are carefully estimated using real-world data, they should be able to provide a steer as to the size of the effects. A well known example is the FRB/US model, used and maintained by researchers at the Federal Reserve Board (Laforte and Roberts, 2014). In a recent speech, Stanley Fischer (2016) uses this model to estimate the impact of a persistent increase in deficit on real rates, and finds that a $1 \mathrm{pp}$ increase in deficit raises the equilibrium rate by between 40 and $50 \mathrm{bps}$, depending on whether the deficit increased because of a tax cut (smaller effect) or a rise in government spending (larger effect). These figures are thus slightly larger than the empirical estimates cited above.

In summary, the estimates in the literature paint a fairly consistent picture: a $1 \mathrm{pp}$ rise in deficit tends to raise interest rates by around 40 basis points; while a 1 percentage point rise in debt/GDP ratio results in an increase of about 3.5 basis points. (Table 2). We suspect this figure is an underestimate of the impact of an exogenous increase in budget deficits on real rates because fiscal expectations are measured with error, because any one country can import capital and so attenuate rate increases when budget deficits increase, and because there will be a tendency - as fiscal policy is used to stabilize the economy - for periods of low neutral real rates to coincide with periods of expansionary fiscal policy. 
Figure 8: Advanced economies $\mathrm{R}^{*}$ adjusted for the impact of government debt

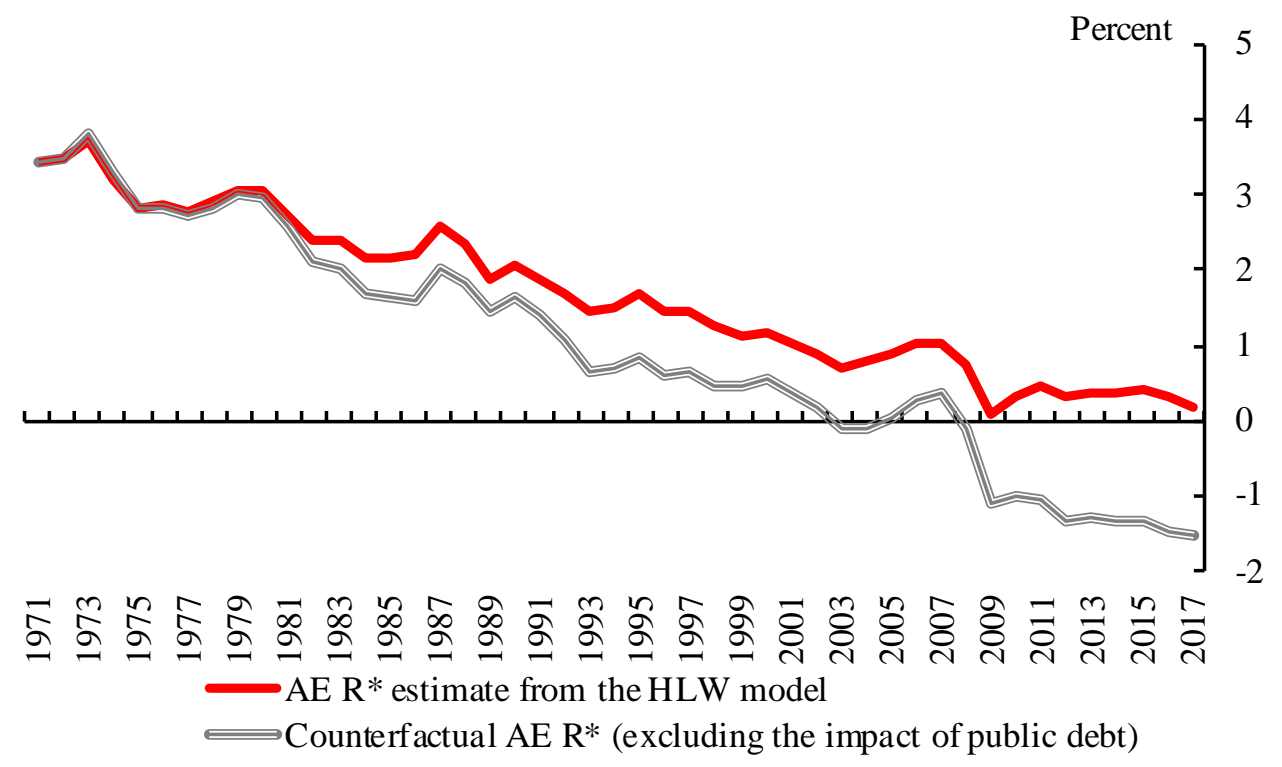

Note: The figure shows the estimated equilibrium real interest rate in advanced economies, and an adjusted measure that subtracts the impact of government borrowing using the average elasticities reported in Table 2.

\subsection{The historical impact of government borrowing on $\mathrm{R}^{*}$}

The elasticities identified in the empirical work combined with the historical path of government borrowing give simple back-of-the-envelope estimates of the historical influence of fiscal policy on real interest rates. Over the past 40 years, the increase in government debt in the OECD has likely pushed interest rates higher, perhaps by as much as $2 \mathrm{pp}$. The measure of $\mathrm{R}^{*}$ that excludes the impact of public debt hovered around zero since the early 2000s, and remains negative at the moment (Figure 8).

\subsection{The link between Social Security and $\mathrm{R}^{*}$}

Social Security constitutes both an intertemporal and a between-group transfer. To be able to calculate by how much changes in Social Security have impacted the neutral real rate, we need the estimates of the impact of Social Security on individual saving, and also the differences in marginal propensities to consume of the groups funding and receiving the Social Security transfer.

A large literature has analyzed the first of those. ${ }^{12}$ Several researchers relied on aggregate time series within a country. An example is the study by Martin Feldstein (1974), who finds a significant offset in the region of 30-50 percent of private saving to Social Security changes in

\footnotetext{
${ }^{12}$ See CBO (1998) for a review.
} 
the US. However, other studies in this literature argued that the effects may be smaller and are highly uncertain. The second approach, based on micro-data in the cross section of individuals, estimates the private sector offset of between 0 and 50\% (e.g. Feldstein and Pellechio (1979)). The cross-country studies find little-to-no effect (e.g. Barro and MacDonald (1979)). More recent papers focus on pension-system reforms to sharpen identification, and find significant responses of private saving (Attanasio and Brugiavini (2003), Attanasio and Rohwedder (2003)). Overall, the literature is consistent with private saving reacting to the changes in Social Security, with elasticities between -0.3 and -0.4 representing the central tendency among a (wide) range of available estimates.

The impact of the between-group transfer depends on the differences in marginal propensities to consume across the two groups: taxpayers and retirees. The traditional life-cycle logic suggests that retirees have a higher marginal propensity to consume relative to working-age individuals, although the evidence on the quantification of these differences is scarce. Carroll et al. (2017) suggest that the difference could be in the region of 0.3 .

Under these assumptions, the increase in Social Security of around 3 percentage points of GDP that we observed (Figure 6) would have led to a decrease in desired saving by around 1pp through the intertemporal channel and another 1pp through the across-groups redistribution. Based on the multipliers used in the calculations underlying Figure 5, the overall 2pp decrease in desired private saving may have led to between 50 and 100 basis points rise in $\mathrm{R}^{*}$. And the rise in old-age healthcare spending would have added further upward pressure on real rates.

To sum up, simple calculations suggest a very substantial upward impact of public policies on $\mathrm{R}^{*}$ over the past half century. To develop further intuition and to consider other mechanisms through which public policy may have affected the interest rate, we now turn to a complementary approach: a general equilibrium modeling framework.

\section{Government policy and $\mathrm{R}^{*}$ : a model-based assessment}

\subsection{Two general equilibrium models}

In Section 4.1 we outlined various channels through which government debt may affect the equilibrium real interest rate; our goal in this Section is to illustrate their quantitative importance within a general equilibrium framework. We want our approach to be simple and transparent, providing a credible complement and a cross-check to the empirical analysis above.

To achieve these goals, we build two general equilibrium models: one capturing the finiteness of life and life-cycle heterogeneity, and another which focuses on precautionary behavior.

The first model, which builds closely on Gertler (1999), highlights life-cycle heterogeneity. 
In this economy, ex-ante identical individuals are at different points in their lives: some are working, some are already retired. This drives the differences in their consumption and saving behavior. The framework is similar to that of Blanchard (1985) and Yaari (1965) - individuals face constant probability of death and so their horizons are finite - but, in addition to their model, workers retire and finance consumption with savings until death.

The second model is a Bewley-Huggett-Aiyagari economy with incomplete markets and uninsurable income risk at the level of an individual household. A similar model was considered by Aiyagari and McGrattan (1998) who also studied the role of government debt on the equilibrium allocation in presence of idiosyncratic risk. The main differences between ours and their approach are that: (i) we calibrate the risk component of the income process to deliver a realistic dose of uncertainty, which implies that distributions of income and assets in the model broadly match distributions observed in developed economies such as the United States; ${ }^{13}$ (ii) we cast the model in continuous time, taking full advantage of the recent analytical and computational discoveries in macroeconomics.

Here we sketch the main workings of the two models and develop the intuition; a more detailed description of the models is available in online Appendix $\mathrm{C}$ for the life-cycle model and Appendix D for the incomplete market model.

\subsection{Model of finite lives and life-cycle heterogeneity}

\subsubsection{Demographics and preferences}

There are two stages of life, work and retirement, with exogenous transition probabilities. That is, each worker faces a given probability of retirement $1-\omega$, and, once a retiree, a given probability of death $1-\gamma$. Population grows at a gross rate $1+n$.

There is no aggregate risk; the only sources of uncertainty facing an individual are the risk of retirement while a worker (associated with a loss of labor income) and a risk of death while a retiree. Left unchecked, these sources of risk would affect agents behavior. This would make aggregation problematic, and, more importantly, it would be unrealistic: timing of retirement is, for the most part, known. To deal with this unrealistic feature, we assume that there are perfect annuity markets for the retirees (neutralizing the influence of the risk of death on their behavior), and that workers' preferences have a certainty equivalence property (such that the risk of retirement does not affect workers' behavior in equilibrium). ${ }^{14}$ These two assumptions are

\footnotetext{
${ }^{13}$ We match the degree of income inequality in the data, but fall short of matching the extreme degree of wealth inequality observed in the real world. We discuss the (standard and well-known) reasons why this is so below.

${ }^{14}$ In particular, workers are assumed to have recursive Epstein and Zin (1991) preferences that generate certainty equivalent decision rules in the presence of income risk.
} 
both realistic and convenient, in that they allow for the derivation of the aggregate consumption function, as we illustrate momentarily.

Specifically, we assume that agents have recursive Epstein-Zin preferences defined as follows:

$$
V_{t}^{z}=\left[\left(C_{t}\right)^{\rho}+\beta^{z} \mathbb{E}_{t}\left\{V_{t+1} \mid z\right\}^{\rho}\right]^{1 / \rho}
$$

where $C_{t}$ denotes consumption, $V_{t}^{z}$ and $\beta^{z}$ stand for agent's $z \in\{w, r\}$ value function and the discount factor respectively, and $\sigma=\frac{1}{1-\rho}$ is the intertemporal elasticity of substitution.

Retirees and workers differ in two crucial respects. First, they have different discount factors. Because of the positive probability of death facing any retiree, their discount factor is the time preference parameter $\beta$ multiplied by the probability of surviving into the next period:

$$
\begin{gathered}
\beta^{w}=\beta \\
\beta^{r}=\beta \cdot \gamma
\end{gathered}
$$

Second, the expectation of the value function next period differs between a worker and a retiree. In particular, a worker takes into account the possibility of retiring, so that her expectation of the value function next period is a probability-weighted sum of the values in the two states:

$$
E_{t}\left\{V_{t+1} \mid w\right\}=\omega V_{t+1}^{w}+(1-\omega) V_{t+1}^{r}
$$

while the expectation of the value function of a retiree is simply given by

$$
E_{t}\left\{V_{t+1} \mid r\right\}=V_{t+1}^{r}
$$

We now outline the problems of the two types of agents.

\subsubsection{Retirees}

Retirees consume out of savings and Social Security payments. Each period, some retirees die. We make the assumption - standard in the literature - that those who survive receive the proportional share of the proceeds. This means that the effective return faced by individual retirees is $R_{t} / \gamma$, higher than the ongoing interest rate $R_{t}{ }^{15}$

Because probability of death is independent of age and the government does not discriminate across retirees in its Social Security transfer policy, each retiree (irrespective of age) solves an

\footnotetext{
${ }^{15}$ For retirees as a group wealth accumulates at the interest rate $R_{t}$, as the higher individual return cancels out with some retirees dying.
} 
identical problem, which is:

$$
V_{t}^{r}=\max _{C_{t}^{r}}\left[\left(C_{t}^{r}\right)^{\rho}+\beta \gamma \mathbb{E}_{t}\left\{V_{t+1}^{r}\right\}^{\rho}\right]^{1 / \rho}
$$

subject to the flow budget constraint:

$$
A_{t+1}^{r}=\left(R_{t} / \gamma\right) A_{t}^{r}-C_{t}^{r}+E_{t}^{r}
$$

where $A_{t}^{r}$ stands for retiree's assets, $C_{t}^{r}$ is her consumption expenditure, and $E_{t}^{r}$ is the Social Security and healthcare cost transfer. ${ }^{16}$

\subsubsection{Workers}

Individuals are born workers and have no assets at the start of life. They consume out of asset wealth and their labour income net of taxes. Because of the demographic structure (in particular the assumption that probability of retirement is independent of age ${ }^{17}$ ), worker's problem is effectively the same no matter the age. Each worker solves:

$$
V_{t}^{w}=\max _{C_{t}^{w}}\left\{\left(C_{t}^{w}\right)^{\rho}+\beta\left[\omega V_{t+1}^{w}+(1-\omega) V_{t+1}^{r}\right]^{\rho}\right\}^{1 / \rho}
$$

subject to:

$$
A_{t+1}^{w}=R_{t} A_{t}^{w}+W_{t}-T_{t}-C_{t}^{w}
$$

where $T_{t}$ are lump-sum taxes levied by the government. ${ }^{18}$

\footnotetext{
${ }^{16}$ Our modeling of healthcare provision is very simple - we treat old-age healthcare cost as a lump-sum transfer, subsumed in the variable $E$.

${ }^{17}$ Of course this is an unrealistic assumption. But, as explained above, the effect of this assumption on workers' behavior is neutralized through the structure of preferences which exhibit a certainty equivalence property. The role of this assumption is thus only to simplify the model and achieve aggregation, with little cost to the economics.

${ }^{18}$ There are two key channels through which life-cycle considerations affect workers' behaviour. First, a worker takes into account the fact that with probability $1-\omega$ she becomes a retiree. This means that, relative to the representative agent case, she discounts the future stream of wages by more: effectively, this is the saving for retirement effect. Mechanically, a larger discount rate reduces the value of human wealth in the consumption function, thus leading to lower consumption and higher saving. Second, a worker discounts the future stream of wealth more because she anticipates that inevitably there will come a time when she becomes a retiree, facing the sad truth that her life is finite. With finite life, wealth can be smoothed out across fewer periods, so its marginal utility value is lower. This effect shows up as a higher effective discount rate applied to future wealth.
} 


\subsubsection{Firms}

The supply side of the model is extremely simple. Market are competitive. Production is carried out by firms employing capital and labor. The aggregate production function is

$$
Y_{t}=K_{t}^{\alpha}\left(X_{t} N_{t}\right)^{1-\alpha}
$$

where $N_{t}$ is the number of workers in the economy. There is exogenous technological progress and population growth, that is $X_{t+1}=(1+x) X_{t}$ and $N_{t+1}=(1+n) N_{t}$. Perfect competition in factor markets means that the wage and the rental rate are equated to the marginal products of the factors: $W_{t}=\alpha \frac{Y_{t}}{N_{t}}$ and $R_{t}=(1-\alpha) \frac{Y_{t}}{K_{t}}+(1-\delta)$. Capital evolves according to the standard law of motion: $K_{t+1}=Y_{t}-C_{t}-G_{t}+(1-\delta) K_{t}$.

\subsubsection{Government}

The government consumes $G_{t}$ each period, and pays retirees a total of $E_{t}$ in Social Security and healthcare benefits. To finance its expenditures the government levies a lump sum tax $T_{t}$ on the workers. It can also issue one period government bonds $B_{t+1}$. The government flow budget constraint is:

$$
B_{t+1}+T_{t}=R_{t} B_{t}+G_{t}+E_{t}
$$

Iterating forward gives the intertemporal budget constraint of the government:

$$
R_{t} B_{t}=\sum_{v=0}^{\infty} \frac{T_{t+v}}{\prod_{z=1}^{v} R_{t+z}}-\sum_{v=0}^{\infty} \frac{G_{t+v}}{\prod_{z=1}^{v} R_{t+z}}-\sum_{v=0}^{\infty} \frac{E_{t+v}}{\prod_{z=1}^{v} R_{t+z}}
$$

That is, the difference between the present discounted valued of government revenue and spending must be exactly equal to the current value of the outstanding debt.

Government policy is exogenous. In particular, it is characterized by the four ratios, $\bar{g}_{t}, \bar{b}_{t}, \bar{e}_{t}, \bar{h}_{t}$, of government consumption, debt, Social Security and healthcare spending to GDP, respectively:

$$
\begin{gathered}
G_{t}=\bar{g}_{t} Y_{t} \\
B_{t}=\bar{b}_{t} Y_{t} \\
E_{t}=\left(\bar{e}_{t}+\bar{h}_{t}\right) Y_{t}
\end{gathered}
$$

Given the paths of $G_{t}, E_{t}$ and $B_{t}$, taxes adjust to satisfy the intertemporal budget constraint. 


\subsubsection{Equilibrium}

In this economy, markets are competitive and agents take prices as given. Formally, a competitive equilibrium is a sequence of quantities and prices such that (i) households maximize utility subject to their budget constraints, (ii) firms maximize profits subject to their technology constraints, (iii) the government chooses a path for taxes, compatible with intertemporal solvency, to finance debt, spending and transfers, (iv) all markets clear.

Appendix $\mathrm{C}$ contains the details of the derivation of the equilibrium conditions of the model. The individual policy functions within the two groups - workers and retirees - aggregate up nicely. Aggregating the two consumption levels, we derive the aggregate consumption function:

$$
C_{t}=C_{t}^{w}+C_{t}^{r}=\pi_{t}\left\{\left(1-\lambda_{t}\right) R_{t} A_{t}+H_{t}+S_{t}^{w}+\epsilon_{t}\left(\lambda_{t} R_{t} A_{t}+S_{t}^{r}\right)\right\}
$$

In this consumption function, $\pi_{t}$ denotes each worker's marginal propensity to consume out of wealth, and $\pi_{t} \epsilon_{t}$ is the MPC of each retiree. These MPCs multiply the total wealth of each group of consumers (with a slight abuse of notation, $A_{t}$ now denotes aggregate financial wealth, $H_{t}$ is aggregate human wealth (the net present value of future wages), and $S_{t}$ stands for the aggregate value of Social Security and healthcare payments). Compared to a standard model, the only additional state variable is the share of wealth held by retirees, $\lambda_{t}$, which fully captures the heterogeneity in the economy.

The total supply of assets is the sum of capital stock $K_{t}$ and government debt $B_{t}$ so that the equilibrium requires:

$$
A_{t}=A_{t}^{w}+A_{t}^{r}=K_{t}+B_{t}
$$

i.e. households asset demand equals the asset supply.

\subsubsection{Calibration and the initial steady state of the life-cycle model}

Despite the richness of the economics, the model is parsimonious and relatively straightforward to calibrate. We set the preferences and technology parameters at the standard values in the macro literature (Table 3). The growth rate of technological change, the demographics parameters and the government policy ratios are all calibrated to match the data in advanced economies in 1970.

Because there is population growth and technological progress in this economy, the steady state equilibrium takes the form of a balanced growth path where all variables grow at a constant gross rate equal to $(1+n)(1+x)$. We can characterize the equilibrium by expressing all variables as ratios in units of effective labor (defining, for any variable $Z_{t}, z_{t} \equiv \frac{Z_{t}}{X_{t} N_{t}}$ ).

Table 4 shows the key variables along the initial (early-1970s) balanced growth path. The 
Table 3: Calibration

\begin{tabular}{llr}
\hline \multicolumn{1}{c}{ Parameter } & \multicolumn{1}{c}{ Description } & Calibration \\
\hline Preferences and technology & & \\
$\beta$ & & 0.98 \\
$\sigma$ & Discount factor & 0.5 \\
$\alpha$ & Intertemporal elasticity of substitution & $1 / 3$ \\
$\delta$ & Capital share & 0.1 \\
$x$ & Depreciation rate & $1.51 \%$ \\
Demographics & Rate of technological change \\
$n$ & & \\
$\frac{1}{1-\omega}$ & & $1.35 \%$ \\
$\frac{1}{1-\gamma}$ & Gross population growth rate \\
Government & Average length of working life (years) & 47.6 \\
$\bar{b}$ & Average length of retirment (years) & 10.5 \\
$\bar{g}$ & & \\
$\bar{e}$ & & 0.18 \\
$\bar{h}$ & Government debt / GDP & 0.14 \\
\hline
\end{tabular}

interest rate is $4.5 \% .^{19}$ As we pointed out above, the key feature of this economy is the heterogeneity in marginal propensities to consume between workers and retirees. Indeed, the endogenous MPC of retirees is over twice that of the workers'. The additional state variable $\lambda-$ the ratio of retirees' wealth in total wealth - takes a plausible value of $17 \%$. Ratios of aggregate consumption, investment, capital and assets to output also match the stylized facts from the data well.

\subsubsection{The simulation exercise}

We now explore how the model economy reacts to changes in government policy. We study four policy levers: government debt, government spending, old-age Social Security and healthcare transfers.

We carry out the following experiment. Starting the economy in the initial 1970s steady state, we feed the model with the policy profiles depicted in Figure 6. Once announced, the profile of these shifts is fully anticipated by the agents. Beyond the current date, we assume that future policy ratios remain constant at their 2017 values. ${ }^{20}$ We then compute the transition

\footnotetext{
${ }^{19}$ With growth rate of $2.9 \%$ per annum, the economy is dynamically efficient.

${ }^{20}$ This is a conservative assumption, as one may reasonably expect the upwards drift in both debt and Social Security spending to continue, at least for some time.
} 
Table 4: The 1970s steady state

\begin{tabular}{llr}
\hline Variable & Description & Value \\
\hline$\psi$ & Ratio of retirees to workers & 0.19 \\
$R$ & Real gross interest rate & 1.045 \\
$\epsilon$ & Ratio of retirees' to workers' MPCs & 2.01 \\
$\pi_{w}$ & Workers' MPC & 0.06 \\
$\pi_{r}$ & Retirees' MPC & 0.13 \\
$\lambda$ & Share of retirees' wealth in total wealth & 0.17 \\
$y$ & Output & 1.50 \\
\multicolumn{2}{c}{ Ratios } & in proportion to output): \\
$c$ & Consumption & 0.57 \\
$c_{r}$ & Consumption of retirees & 0.11 \\
$c_{w}$ & Consumption of workers & 0.45 \\
$a$ & Assets & 2.42 \\
$a_{r}$ & Assets of retirees & 0.40 \\
$a_{w}$ & Assets of workers & 2.03 \\
$h$ & Human capital & 4.23 \\
$i$ & Investment & 0.27 \\
$k$ & Capital & 2.25 \\
$\tau$ & Taxes & 0.21 \\
$s$ & Social Security wealth of the retirees & 0.50 \\
$s_{w}$ & Social Security wealth of the workers & 0.91 \\
\hline
\end{tabular}

path towards this new steady state.

Our focus is on the response of the interest rate to these policy shifts. Figure 9 contains the main result of this Section: the total response of the interest rate to the policy changes discussed above. This response is quantitatively large: according to the model, government policies pushed up on the equilibrium interest rate by around 3.2pp over the past 50 years. Moreover, the model suggests that further upward pressure is to be expected as the economy settles at the new steady state. All of the policies except government spending - which did not change much - play an important role. The final set of bars, labelled "Interactions", is the additional effect on the interest rate from the (non-linear) synergies between the three different policies. ${ }^{21}$

\subsection{A model of precautionary savings}

We now turn to the model of precautionary behavior, which is a continuous time version of the Aiyagari and McGrattan (1998) economy. Population consists of a large number of infinitely-

\footnotetext{
${ }^{21}$ More precisely, the interaction effect exists because the final steady state is a non-linear system of equations. These non-linearities make the overall effect of several exogenous changes different, in general, from the sum of the parts.
} 
Figure 9: Simulated impact of government policies on the equilibrium real interest rate in the life-cycle model

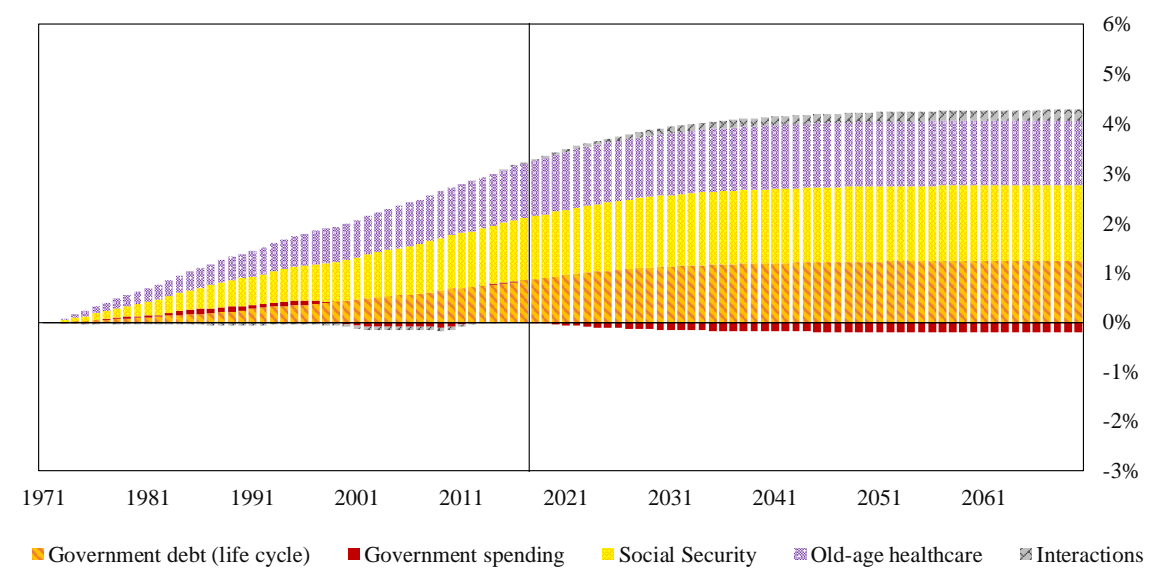

Notes: The figure shows how the equilibrium real interest rate adjusts to the exogenously given paths of government debt, spending, and old-age Social Security transfers depicted in Figure 6. The 2017 values in Figure 6 are assumed to be the new steady state values.

lived individuals of measure 1. Every individual is ex-ante identical, but people face shocks to their income which they cannot fully insure against: markets are incomplete. As a result of this idiosyncratic risk, individuals experience different income histories and thus accumulate different levels of wealth. All the risk is at the individual level: for simplicity, we abstract from aggregate uncertainty.

Our goal here is to assess quantitatively the influence government debt has on precautionary behavior. In other words, how different is the prevailing interest rate when government debt-toGDP ratio is $18 \%$ vs. when it is $68 \% ?^{22}$

\subsubsection{Brief outline of the model}

An individual chooses consumption and asset holdings to maximize her expected utility, subject to the flow budget constraint, the consumption non-negativity constraint, the borrowing

\footnotetext{
${ }^{22}$ Our model is highly stylized and abstracts from important features present in more advanced and larger models in the literature. We view our model here as an early attempt to quantify the precautionary saving channel of government debt. Richer features may usefully be incorporated in future attempts to answer this question. For analysis of saving rates across the distribution, see Straub (2017) and Fagereng et al., (forthcoming). For evidence on the differential rates of return, see Fagereng et al. (2016). For models with multiple assets or a more careful analysis of the constraint - both of which contribute to a better match to the empirical distribution around the borrowing constraint, see Kaplan et al. (2014), Kaplan et al. (2018) and Achdou et al. (2017). For the state-of-the-art calibration of the income process, see Guvenen et al. (2015). We conjecture that a richer model with some of the above features would likely predict larger effects of government policy.
} 
constraint and a realization of the idiosyncratic income shock:

$$
\max _{\left\{c_{t}\right\}_{t \geq 0}} \mathbb{E} \int_{0}^{\infty} e^{-\rho t} \frac{c_{t}^{1-\sigma}}{1-\sigma} d t
$$

subject to

$$
\begin{aligned}
\dot{a}_{t} & =(1-\tau) w_{t} e_{t}+(1-\tau) r_{t} a_{t}-c_{t} \\
c_{t} & \geq 0 \\
a_{t} & \geq \underline{a} \\
e_{t} & \in\left\{z_{1}, \ldots, z_{n}\right\}
\end{aligned}
$$

where $c_{t}$ is individual consumption, $a_{t}$ are individual asset holdings (and $\dot{a}_{t}$ denotes the time derivative, i.e. saving), $r_{t}$ is the real (net) interest rate, $w_{t}$ is the wage, $e_{t}$ is the idiosyncratic shock to household's productivity. The household cannot insure against that idiosyncratic uncertainty. The government levies a proportional tax rate $\tau$ on both labor and capital income. ${ }^{23}$

The supply side is identical to that in the previous model: production function is CobbDouglas and there is perfect competition in all markets. Government issues bonds and collects taxes to finance its consumption and transfers. The government budget constraint is

$$
\dot{B}_{t}=G_{t}+r_{t} B_{t}-\tau\left(w_{t}+r A_{t}\right)
$$

which says that the change in government debt is equal to the government funding gap: government consumption $G_{t}$ plus interest payments $r_{t} B_{t}$ minus the tax revenue.

Online Appendix D presents the definition and solution of the equilibrium of this economy.

\subsubsection{Parametrization}

We choose the values of the parameters in the precautionary savings model to match the typical values in the literature and to be broadly consistent with the life-cycle model above (Table 3). We set the capital share at $\frac{1}{3}$, the rate of time preference at 0.04 , the depreciation rate at $10 \%$ and the IES at $\frac{1}{2}$.

We next calibrate the income process. Intuitively, size and persistence of income shocks will determine the strength of the precautionary savings motive, the degree of inequality, and the proportion of households close to or at the borrowing constraint. These outcomes will in turn

\footnotetext{
${ }^{23}$ The assumption of a proportional tax rate is natural in a model with income and wealth heterogeneity. With lump-sum taxation, the poorest households would find themselves unable to pay the tax bill. Note that even though the tax is proportional it does not distort the labor supply decisions as the labor supply is inelastic.
} 
determine the potency of government financing policy. In the real world, individual income varies over time for a host of reasons. We do not model these causes here. Instead, we make sure that the income process in our model reflects these uncertainties. Specifically, we follow Castañeda et al. 2003 and Winter (2016) and calibrate the income process to match aggregate income inequality in the OECD. There are four productivity and income states:

$$
e \in\{0.20,0.55,0.80,5.43\}
$$

The corresponding matrix of Poisson intensities is

$$
P=\left(\begin{array}{cccc}
0.07^{-} & 0.04 & 0.02 & 0.001 \\
0.03 & 0.13^{-} & 0.01 & 0.001 \\
0.001 & 0.08 & 0.09^{-} & 0.011 \\
0.1 & 0.02 & 0.06 & 0.17^{-}
\end{array}\right)
$$

where the values on the main diagonal marked with superscript - indicate the intensity of leaving the current state.

Given this income process, the distributional outcomes in the equilibrium of our model are broadly in line with those observed in the data: the income Gini coefficient is 0.32, close to the OECD average, and the income process is highly persistent. ${ }^{24}$

\subsubsection{Results}

We now compare the two stationary equilibria of the model, one with the government debt / GDP ratio set at 18\%, and another at $68 \%$, to see what the impact of such higher pool of assets is on the interest rate. Because a larger amount of assets allows households to better insure against individual uncertainty, we expect the interest rate to be higher when government debt is high. The simulation results confirm this intuition: the increase in public debt / GDP ratio observed in the data implies a real interest rate that is 66 basis points higher in equilibrium (Table 5 ). While not insignificant, such an increase is smaller than the other channels we identified above.

\subsection{Summary and discussion}

In summary of this Section, our analysis underscores the importance of secular public policy shifts in accounting for changes in the equilibrium interest rate. The natural corollary of our findings is that government intra- and intertemporal transfer policy is, in principle, an effective

\footnotetext{
${ }^{24}$ Castañeda et al. (2003) compare the across-the-income-distribution mobility statistics implied by their model with those observed in the data and conclude that the simple model does reasonably well in capturing the persistence moments.
} 


\begin{tabular}{ccc}
\hline & Low Debt Equilibrium & High Debt Equilibrium \\
\hline Government debt / GDP & 0.18 & 0.68 \\
Government consumption / GDP & 0.14 & 0.14 \\
Average tax rate & 0.35 & 0.36 \\
Real interest rate & 4.50 & 5.16 \\
Private capital / GDP & 2.56 & 2.40 \\
Income Gini & 0.32 & 0.32 \\
Fraction of individuals at the constraint & 0.09 & 0.09 \\
\hline
\end{tabular}

Table 5: Equilibria in the precautionary saving model

tool that can affect equilibrium interest rates in the economy. Similar policy implications have been discussed previously by Kocherlakota (2015) and Caballero and Farhi (2014).

One objection to our analysis might be that economic agents - consumers, investors, firms etc. - may in fact be more Ricardian than we currently assume. Our response to this is three-fold. First, in Section 3 we presented a broad range of empirical evidence that is inconsistent with the Ricardian Equivalence proposition. Second, in our framework, Ricardian Equivalence does not hold despite fully rational expectations and no information asymmetries: indeed, it would be irrational to be Ricardian in the economy we describe. Third, and relatedly, the assumptions that lead to rejection of Ricardian Equivalence are rather natural (i. people retire; ii. people die; iii. some people are credit constrained; iv. some people face risks they find hard to insure). All those considerations make us comfortable with our assumptions that the Ricardian offset is imperfect.

At this point it is also useful to highlight that wide uncertainty bands surround our point estimates, including those coming out of the models discussed above. Like all theory models, these tools are built upon a set of uncertain assumptions, and as such are only rough approximations of reality - this is especially true for models as minimalistic and transparent as ours. Even abstracting from model misspecification, there is a wide range of plausible parameter values with which to calibrate these models. A different combinations of parameters will produce quantitatively different results. We come back to the robustness of our analysis in Appendix E. Having said that, the combination of a range of empirical studies together with directional guidance from the theory suggest that there are strong reasons to conclude that the government policies we scrutinized here have put significant upward pressure on safe neutral real rate over the past several decades. 


\section{Validating the models by assessing the underlying weak- ness in $\mathrm{R}^{*}$}

Our simulation analysis concluded that the major shifts in governments' policies over the past 50 years facilitated a significant transfer of resources from low-MPC to high-MPC individuals and permitted households to self-insure against idiosyncratic shocks. All else equal, added together these shifts would have pushed interest rates in advanced world up by around 3.6pp. But of course all else was not equal. In this Section we validate our models by showing that, when used to assess the impact of some of the private sector forces that have been highlighted by the literature, these models produce the quantitative impacts that are plausible and in line with the existing findings. Specifically, our framework can readily be used to quantify the impact of the demographic transition, decline in expected trend productivity growth and the rise in income inequality on the long-term interest rate.

Table 6 documents the major demographic transition that has been underway in advanced economies for the past 50 years. Population growth in the developed economies has fallen rapidly in past decades, from around $1.4 \%$ per annum in 1970 s to less than $0.4 \%$ today. This trend is expected to continue; in fact, the latest UN projections suggest that population in advanced economies will start shrinking around 2050. As population growth decelerated, life expectancy has gone up significantly, and retirement ages did not keep up. As a result, the average length of retirement is nearly twice what it was in the 1970s. This positive development carries significant implications for life-cycle budgeting and thus for the balance of desired saving and investment.

The slowdown in the pace of expected long-run growth has similar implications. Our modeling framework inherits the property shared by essentially all dynamic macroeconomic models, namely that the long-run equilibrium interest rate is linked to the expected future consumption growth. This relationship - the Euler Equation or the dynamic IS curve - is the result of intertemporal optimization of households, who choose how much to consume today vs. tomorrow (hence determining the growth rate of their consumption) based on the interest rate. In general equilibrium, the expectations of future consumption growth in the long-run coincide with the expectations of TFP growth. Hence the theory suggests that real rates and expected productivity growth ought to be linked. ${ }^{25}$

This prediction of the theory is, however, more tenuous in practice. In an early contribution

\footnotetext{
${ }^{25}$ In a representative agent, infinite-horizon economy, the Euler Equation takes a particularly straightforward form, whereby long-run consumption growth rate and the interest rate are linked linearly, with the coefficient equal to the intertemporal elasticity of substitution. Within our framework, that link is still there, although it is attenuated by finite horizons and borrowing constraints: intuitively, the interest rate is relatively "less important" in driving consumption growth, as other factors (such as possibility of death or credit constraints) come into play. This implies that a given change in the expectations of future consumption growth - driven by news about TFP, say - will require a larger response of the interest rate to restore equilibrium.
} 
Table 6: Demographic transition in advanced economies

\begin{tabular}{ccccc}
\hline & Growth of 20+ population & Retirement age & Years working & Years in retirement \\
\hline 1970 & 1.4 & 67.6 & 47.6 & 10.5 \\
1975 & 1.3 & 66.6 & 46.6 & 12.3 \\
1980 & 1.2 & 66.1 & 46.1 & 13.4 \\
1985 & 1.1 & 65.1 & 45.1 & 15.0 \\
1990 & 0.9 & 64.7 & 44.7 & 16.1 \\
1995 & 0.8 & 63.8 & 43.8 & 17.5 \\
2000 & 0.7 & 63.6 & 43.6 & 18.6 \\
2005 & 0.8 & 64.1 & 44.1 & 18.9 \\
2010 & 0.7 & 64.8 & 44.8 & 18.8 \\
2015 & 0.4 & 65.5 & 45.5 & 18.7 \\
Projection: & & & & \\
2020 & 0.2 & 66.1 & 46.1 & 18.6 \\
2025 & 0.2 & 66.8 & 46.8 & 18.4 \\
2030 & 0.2 & 67.5 & 47.5 & 18.3 \\
\hline
\end{tabular}

Sources: United Nations and OECD.

to this topic, Christopher Carroll and Lawrence Summers (1991) established that, across countries, consumption growth and income growth are tightly linked and follow each other, and that households with more steeply rising income profiles tend to save more, not less. These findings - inconsistent with the standard permanent-income hypothesis and the life cycle model - have been rationalized in the literature with buffer-stock models of savings (whereby households face uncertain income process, similarly to our second model) and introducing consumption habits in household preferences. ${ }^{26}$ While our models attenuate the link between interest rates and consumption choices in line with these findings, nonetheless we urge a significant degree of caution when interpreting the results on the link between TFP and $\mathrm{R}^{*}$. Our preferred interpretation is that the low interest rates today are chiefly a symptom of a demand-side problem. We return to this issue in the final section of the paper where we discuss policy implications.

These caveats notwithstanding, numerous studies - for instance, Adler et al. (2017) - reach the conclusion that trend growth rates of both productivity and of TFP have declined significantly in advanced economies, first in the early 1980s when TFP growth halved from about $2 \%$ to $1 \%$ per annum, and then again in the mid-2000s, and the macroeconomic models we use do suggest that such deterioration should have dragged on neutral real interest rates.

The third trend we quantify is the rise in income inequality, which has increased in the United States and many other advanced economies (Figure 10). Our second model is well suited

\footnotetext{
${ }^{26}$ See Deaton (1991), Carroll (1997) and Carroll et al. (2000) and the literature that followed.
} 
to give us an estimate of this shift on the real rate of interest. To trace out the effects of rising inequality in this model, we recalibrate the income process in such a way as to match the increase in income Gini coefficient in the OECD since the 1970s. Our calculations implicitly assume that ex-post inequality is driven by larger variance of individual income shocks, which constitutes a source of additional uncertainty for individual workers. An alternative view is that the increase in inequality is a consequence of shifts more tightly linked to heterogeneity across households that is known ex-ante. The distinction is important because only the former kind of shift would lead to an increase in precautionary behavior. Because it is predictable, the latter shift is not associated with heightened risk. There is a long-standing debate about the merits of the two formulations in the literature. ${ }^{27}$ The recent work by Fatih Guvenen and co-authors has established the large departures of log-normality in the individual income changes: in particular, earnings changes display strong negative skewness and extremely high kurtosis. Important for our interpretation is their finding that large shocks at the top of the income distribution tend to be very persistent. We view these results as supportive of the gist of our exercise, which interprets the increased disparity between the poor and the rich as going hand in hand with an increase in ex-ante uncertainty. Given the lack of clear consensus in the literature, it is possible that we overestimate the impact of inequality on real rates in this exercise. In any case, there likely are other powerful ways in which higher inequality has acted to depress rates, which we miss from our framework (and which we discuss momentarily).

To validate our models and to explore the implications of these trends for the equilibrium real interest rate, we perform the following exercise: in the life-cycle model, we calibrate the changes in demographic transition probabilities, $\omega$ and $\gamma$, to match the trends depicted in the final two columns of Table 6 . We then feed in the series for population and TFP growth rates to match the evidence in the first column of Table 6 and Adler et al. (2017). We use the UN demographic projections to inform the path of demographics out to 2050, and assume that the terminal 2050 values are the steady state. We do not have a strong prior as to the path for future TFP growth, and we are well aware of the wide range of existing and plausible views. Aiming for a scenario that reflects the mode of these expectations, we assume that the TFP growth rate picks up from around zero in the latest available data to $0.7 \%$ in the long-run. ${ }^{28}$ This pick-up in TFP growth is broadly in line with the CBO's assumption for the pickup of TFP growth in the United States (The U.S. Congressional Budget Office (2019)).

\footnotetext{
${ }^{27}$ Classic references include Lillard and Weiss (1979), MaCurdy (1982) and Guvenen (2009).

${ }^{28}$ There is very large uncertainty around any long-term forecast of the TFP growth rate. In particular, research has shown that current-decade growth of productivity holds little information as to the growth in the following decade. Perhaps naturally, the commentators are split on the prospects for innovation and productivity. See, for example, Brynjolfsson and McAfee (2014) and Gordon (2016) for two perspectives from the opposite ends of a spectrum.
} 
Figure 10: Gini coefficient of disposable household income across the OECD

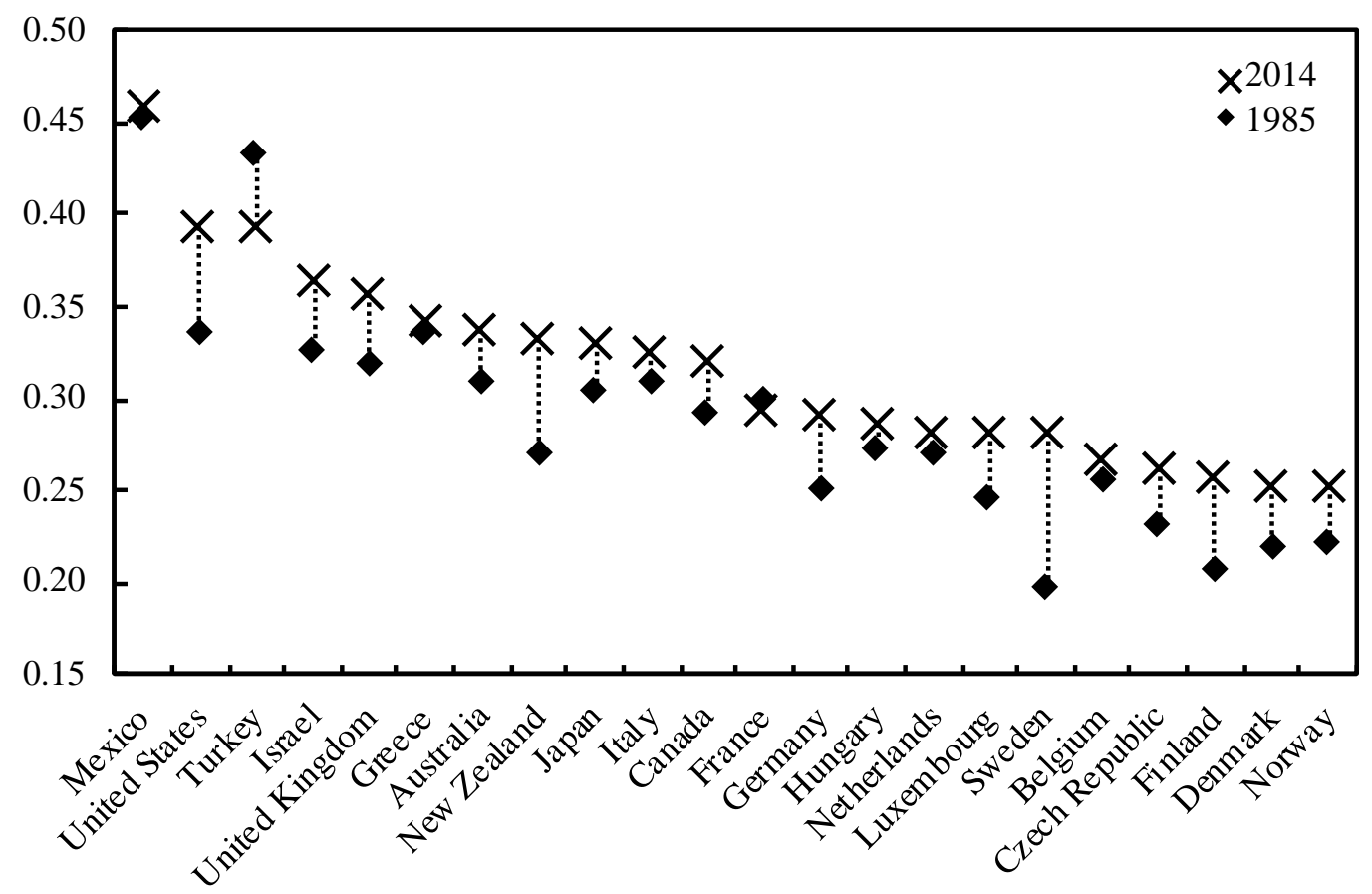

Source: OECD Database on Household Income Distribution and Poverty. Disposable income adjusted for household size.

In the precautionary saving model, we recalibrate the income process ${ }^{29}$ and compare the steady states of the economy under the two calibrations. ${ }^{30}$

To reiterate, within each of the two models, we feed in the (model-specific) set of shocks all at the same time, thereby providing - within each model - an internally consistent laboratory to study this wide range of heterogenous trends. What we miss are the potential interactions across the two models. We assume that the comparable calibration across the two frameworks makes the results comparable and that simply adding the estimates of the impact on $\mathrm{R}^{*}$ over the transition across the models results in a consistent picture. But ultimately, only the framework for analysis of all the forces that we consider - and perhaps further ones - in a single unifying setting would provide a definitive answer to these doubts. This avenue of inquiry is left for future work.

Table 7 and Figure 11 summarize the key results of this exercise. First, in Section 3 we estimated that the neutral real rate has declined by over 3pp between 1970 and 2017. In Sections

\footnotetext{
${ }^{29}$ In particular, we change the income received in the highest income state. This is motivated by the fact that the increase in income inequality has been concentrated at the very top of the distribution, as documented by Piketty (2014) and others.

${ }^{30}$ We obtain the dynamic path by assuming that the effect builds steadily, including over the next decade. Our treatment of the dynamics is thus crude. We leave the analysis of the dynamic adjustment path for future work.
} 
Table 7: Decomposition of the decline in the neutral real interest rate in Advanced Economies

\begin{tabular}{lccc}
\hline & $1970-2008$ & $1970-2017$ & $1970-2070$ \\
\hline Estimated decline in AE R* (Sec 3) & $\mathbf{- 2 . 7}$ & $\mathbf{- 3 . 2}$ & \\
& & & \\
Public policies & & & \\
Government debt (life-cycle) & 0.6 & 0.8 & 1.2 \\
Government debt (incomplete markets) & 0.3 & 0.4 & 0.7 \\
Government spending & -0.1 & 0.0 & -0.2 \\
Social Security & 1.0 & 1.2 & 1.5 \\
Old-age healthcare & 0.9 & 1.1 & 1.3 \\
Total impact of public policies & 2.8 & 3.6 & 4.5 \\
& & & \\
Implied decline in private sector R* & $-\mathbf{5 . 4}$ & $\mathbf{- 6 . 9}$ & \\
& & & \\
Selected private sector forces & & & \\
TFP growth & -1.5 & -1.8 & -1.5 \\
Population growth & -0.5 & -0.6 & -1.3 \\
Longer retirement & -1.0 & -1.1 & -1.2 \\
Length of working life & -0.1 & -0.1 & 0.0 \\
Inequality & -0.6 & -0.7 & -0.9 \\
Interactions & -0.8 & -1.1 & -1.6 \\
Total private sector forces & -4.4 & -5.5 & -6.5 \\
\hline
\end{tabular}

Note: all values are in percentage points.

4 and 5 we argued that public policies pushed rates up. Our models suggest that, together, the policies we considered have pushed rates up by nearly 4pp to date. This suggests that the private sector $\mathrm{R}^{*}$ may have declined by around $7 \mathrm{pp}$. The private sector forces we consider add up to a drag of $5.5 \mathrm{pp}$, leaving over $1 \mathrm{pp}$ of the decline in private sector $\mathrm{R}^{*}$ unaccounted for. These results are in line with previous papers that have attempted the quantification of the different forces at play (see, for example, Eggertsson et al. (2019), Carvalho et al. (2015) and Gagnon et al. (2016)). This makes us confident that the large quantitative effect of government policies that we estimated are credible and not just a result of model-specific assumptions or calibration.

Unsurprisingly, the forces that we consider in this exercise cannot account for the full extent of the decline in equilibrium rates, with over 1pp left unexplained in our preferred calibration. Our models miss some of the secular forces that likely pushed neutral rates lower over the past 40 years. One omission is the increasing concentration and the associated increase in market power of firms in the US and other advanced countries (Farhi and Gourio (2018)). Another force is driven by the finding that propensities to save are higher for those with high permanent 
Figure 11: Changes in the equilibrium real interest rate as a result of policy, demographic and technological shifts

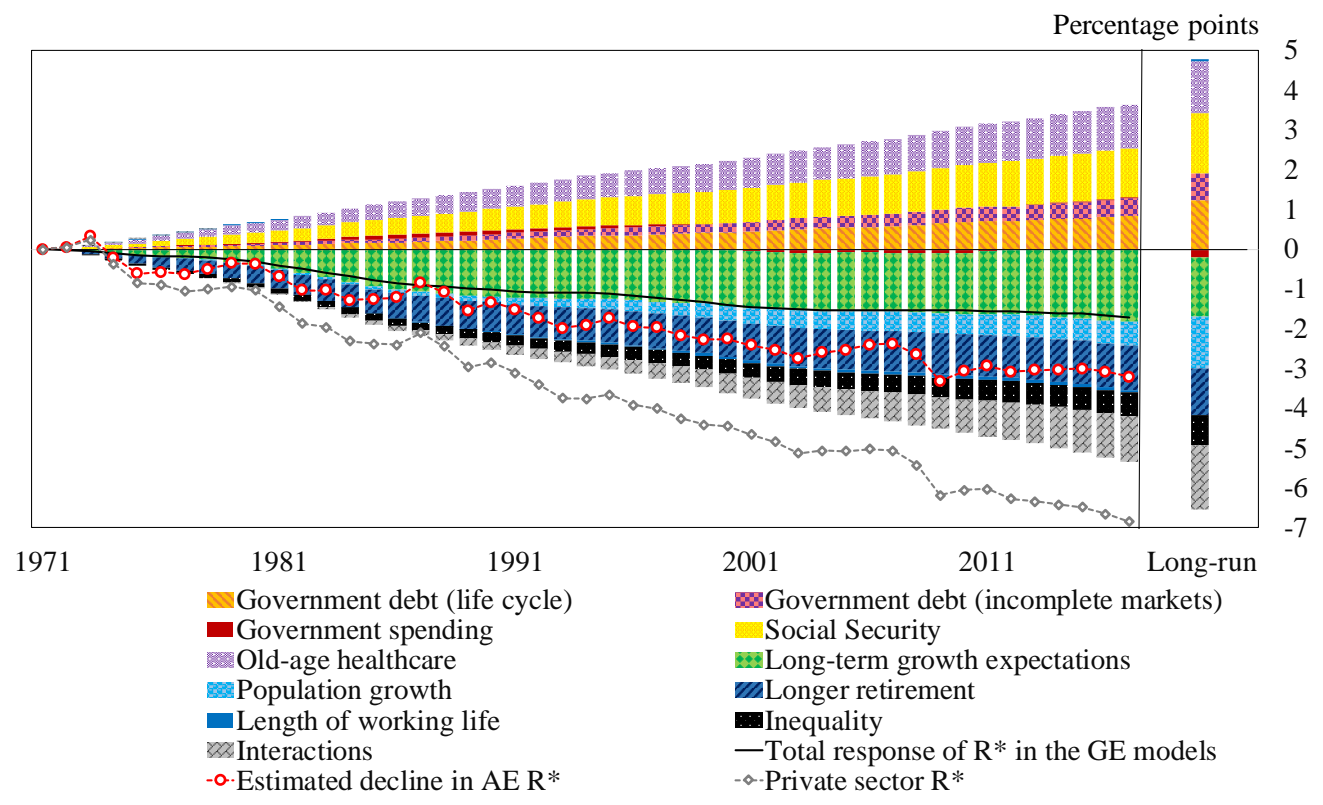

income (Carroll (2000), Dynan et al. (2004)). In light of these findings, our simulations likely understate the full impact of the increase in permanent income inequality. Using a model which captures this mechanism, Ludwig Straub (2017) estimates that the rise in inequality may have pushed down on the real equilibrium interest rate in the US by about 1pp through this channel. The decline in the price of capital goods may have contributed to lower investment propensities, further decreasing the neutral real rate (Sajedi and Thwaites (2016)). Finally, changes in the tax code - particularly the decline in overall tax progressivity in some jurisdictions - may have been a public sector force that depressed interest rates. We leave more detailed investigation of these forces for future work.

\section{Conclusion}

We draw three main conclusions from the analysis in this paper. First, the neutral real rate for the industrial world has trended downward for the last generation and this is best understood in terms of changes in private sector saving and investment propensities. In the face of neutral real rate estimates, past trends in indexed bond yields, and measures of real swap yields, this conclusion seems inescapable. It is also noteworthy that current real rates appear to be quite well predicted by pre-financial crisis trends. We believe that the these trends are best analyzed in terms of changes in saving and investment propensities or equivalently in terms of trends in desired wealth holdings by consumers and desired capital accumulation by producers. While 
factors involving liquidity, scarcity and risk no doubt bear on levels of real interest rates we find it highly implausible that they are the main factor accounting for trend movements. The movements are too large and too pervasive across assets and the fluctuations in spreads are too small and lacking in trend for these factors to account for the observed trends in the data.

Second, the neutral real rate would have declined substantially more over the last generation but for increases in government debt and expansions in social insurance programs. Both straightforward extrapolations of existing rules of thumb regarding debt and deficit impacts on interest rates and calculations using workhorse general equilibrium models suggest that fiscal policies have operated to raise real interest rates by several hundred basis points over the last generation. While this conclusion is dependent on our rejection of Ricardian equivalence, we see nothing that leads us to believe that increased government debt automatically calls for increased saving or that pay-as-you-go Social Security programs alter bequests for most families. The specific magnitudes are very uncertain, but open economy aspects and the possibility suggested by our analysis - that budget deficits emerge in response to excesses of private saving over private

investment - lead us to think that we are more likely to understate than overstate the extent of fiscal support for real interest rates in recent years.

Third, the implication of our analysis that but for major increases in deficits debt and social insurance neutral real rates in the industrial world would be significantly negative by as much as several hundred basis points suggests substantial grounds for concern over secular stagnation. From the perspective of our analysis the private economy is prone to being caught in a lowinflation underemployment equilibrium if real interest rates cannot fall far below zero. These conclusions highlight the importance of ongoing and future work that considers adequate policy responses.

\section{References}

Achdou, Y., Han, J., Lasry, J.-M., Lions, P.-L., and Moll, B. (2017). Income and Wealth Distribution in Macroeconomics: A Continuous-Time Approach. Technical report, National Bureau of Economic Research, Cambridge, MA.

Adler, G., Duval, R., Furceri, D., Kiliç Çelik, S., Koloskova, K., and Poplawski-Ribeiro, M. (2017). Gone with the Headwinds: Global Productivity.

Aiyagari, R. S. (1993). Uninsured Idiosyncratic Risk and Aggregate Saving. Source: The Quarterly Journal of Economics, 109184(3):659-684.

Aiyagari, S. and McGrattan, E. R. (1998). The optimum quantity of debt. Journal of Monetary Economics, 42(3):447-469. 
Attanasio, O. P. and Brugiavini, A. (2003). Social Security and Households' Saving. Technical Report 3.

Attanasio, O. P. and Rohwedder, S. (2003). Pension wealth and household saving: Evidence from pension reforms in the United Kingdom. American Economic Review, 93(5):1499-1521.

Barro, R. J. (1974). Are Government Bonds Net Wealth? Journal of Political Economy, $82(6): 1095-1117$.

Barro, R. J. and MacDonald, G. M. (1979). Social security and consumer spending in an international cross section. Journal of Public Economics, 11(3):275-289.

Blanchard, O. J. (1985). Debt, Deficits, and Finite Horizons. The Journal of Political Economy, $93(2): 223-247$.

Brook, A.-m. (2003). Recent and Prospective Trends in Real Long-Term Interest Rates.

Brynjolfsson, E. and McAfee, A. (2014). The second machine age : work, progress, and prosperity in a time of brilliant technologies. W. W. Norton \& Company, 2014.

Caballero, R. J. and Farhi, E. (2014). The safety trap. NBER Working Paper.

Caballero, R. J. and Farhi, E. (2018). The safety trap. Review of Economic Studies, 85(1):223274.

Caballero, R. J., Farhi, E., and Gourinchas, P. O. (2016). Safe asset scarcity and aggregate demand. In American Economic Review, volume 106, pages 513-518.

Carroll, C., Slacalek, J., Tokuoka, K., and White, M. N. (2017). The distribution of wealth and the marginal propensity to consume. Quantitative Economics, 8(3):977-1020.

Carroll, C. D. (1997). Buffer-Stock Saving and the Life Cycle/Permanent Income Hypothesis. The Quarterly Journal of Economics, 112(1):1-55.

Carroll, C. D. (2000). Why Do the Rich Save So Much? In Does Atlas Shrug? The Economic Consequences of Taxing the Rich., pages 465-84.

Carroll, C. D., Overland, J., and Weil, D. N. (2000). Saving and Growth with Habit Formation. American Economic Review, 90(3):341-355.

Carroll, C. D. and Summers, L. H. (1991). Consumption Growth Parallels Income Growth: Some New Evidence. In National Saving and Economic Performance, pages 305 - 348. 
Carvalho, C., Ferrero, A., and Nechio, F. (2015). Demographics and Real Interest Rates :. pages $1-29$.

Castañeda, A., Díaz-Giménez, J., and Ríos-Rull, J.-V. (2003). Accounting for the U.S. Earnings and Wealth Inequality. Journal of Political Economy, 111(4):818-857.

CBO (1998). Social Security and Private Saving: a Review of the Empirical Evidence. Technical report.

Christensen, J. H. E. and Rudebusch, G. D. (2017). A New Normal for Interest Rates? Evidence from Inflation-Indexed Debt. Federal Reserve Bank of San Francisco, Working Paper Series, pages $01-39$.

Claessens, S. and Kose, M. A. (2017). Asset prices and macroeconomic outcomes: a survey. Technical report.

D’Amico, S., Kim, D. H., and Wei, M. (2018). Tips from TIPS: The Informational Content of Treasury Inflation-Protected Security Prices. Journal of Financial and Quantitative Analysis, 53(1):395-436.

Deaton, A. (1991). Saving and Liquidity Constraints. Econometrica, 59(5):1221-1248.

Del Negro, M., Giannoni, M. P., Giannone, D., and Tambalotti, A. (2018). Global Trends in Interest Rates. Federal Reserve Bank of New York Staff Reports, 2018(866).

Diamond, P. A. (1965). National Debt in a Neoclassical Growth Model. American Economic Review, 55(4):1126-1150.

Dynan, K., Skinner, J., and Zeldes, S. (2004). Do the Rich Save More? Journal of Political Economy, 112(2):397-444.

Eggertsson, G. B., Mehrotra, N. R., and Robbins, J. A. (2019). A Model of Secular Stagnation: Theory and Quantitative Evaluation. American Economic Journal: Macroeconomics, 11(1):148.

Elmendorf, D. W. and Mankiw, N. G. (1999). Government debt. In Handbook of Macroeconomics, pages $1615-1669$.

Engen, E. and Hubbard, R. G. (2004). Federal Government Debts and Interest Rates.

Engen, E. M. and Gruber, J. (2001). Unemployment insurance and precautionary saving. Journal of Monetary Economics, 47(3):545-579. 
Epstein, L. G. and Zin, S. E. (1991). Substitution, Risk Aversion, and the Temporal Behavior of Consumption and Asset Returns: An Empirical Analysis. Journal of Political Economy, 99(2):263-286.

Fagereng, A., Guiso, L., Malacrino, D., and Pistaferri, L. (2016). Heterogeneity and Persistence in Returns to Wealth.

Fagereng, A., Holm, M., Moll, B., and Natvik, G. (2018). Saving Behavior across the Wealth Distribution.

Faini, R. (2006). Fiscal policy and interest rates in Europe. Economic Policy, 21(47):444-489.

Farhi, E. and Gourio, F. (2018). Accounting for Macro-Finance Trends: Market Power, Intangibles, and Risk Premia.

Feldstein, M. (1974). Social Security, Induced Retirement, and Aggregate Capital Accumulation. Journal of Political Economy, 82(5):905-926.

Feldstein, M. and Pellechio, A. (1979). Social Security and Household Wealth Accumulation: New Microeconometric Evidence. Technical Report 3.

Fischer, S. (2016). Why Are Interest Rates So Low? Causes and Implications. Technical report.

Gagnon, E., Johannsen, B., and Lopez-Salido, D. (2016). Understanding the New Normal: The Role of Demographics. Finance and Economics Discussion Series, 2016(080).

Gale, W. G. and Orszag, P. R. (2002). The Economic Effects of Long-Term Fiscal Discipline. Urban-Brookings Tax Policy Center Discussion Paper.

Gali, J. (2008). Monetary policy, inflation, and the business cycle : an introduction to the new Keynesian framework and its applications.

Gertler, M. (1999). Government debt and social security in a life-cycle economy. CarnegieRochester Conference Series on Public Policy, 50:61-110.

Gordon, R. J. (2016). Perspectives on the rise and fall of American growth. In American Economic Review, volume 106, pages 72-76.

Guvenen, F. (2009). An empirical investigation of labor income processes. Review of Economic Dynamics, 12(1):58-79. 
Guvenen, F., Karahan, F., Ozkan, S., and Song, J. (2015). What do Data on Millions of U.S. Workers Reveal About Life-Cycle Earnings Risk? NBER Working Paper Series, January(wp29013).

Hamilton, J. D. (1994). Time series analysis. Princeton University Press, Princeton, N.J.

Hamilton, J. D., Harris, E. S., Hatzius, J., and West, K. D. (2016). The Equilibrium Real Funds Rate: Past, Present, and Future. IMF Economic Review, 64(4):660-707.

Havranek, T., Horvath, R., Irsova, Z., and Rusnak, M. (2015). Cross-country heterogeneity in intertemporal substitution. Journal of International Economics, 96(1):100-118.

Ho, P. (2018). Estimating the Effects of Demographics on Interest Rates: A Robust Bayesian Perspective.

Holston, K., Laubach, T., and Williams, J. C. (2017a). Documentation of R Code and Data for Measuring the Natural Rate of Interest: International Trends are Determinants.

Holston, K., Laubach, T., and Williams, J. C. (2017b). Measuring the natural rate of interest: International trends and determinants. Journal of International Economics, 108:S59-S75.

Jordà, Ò., Schularick, M., and Taylor, A. M. (2016). Macrofinancial History and the New Business Cycle Facts. NBER Macroeconomics Annual 2016, 31.

Kaplan, G., Moll, B., and Violante, G. L. (2018). Monetary Policy According to HANK. American Economic Review, 108(3):697-743.

Kaplan, G., Violante, G. L., and Weidner, J. (2014). The wealthy Hand-to-Mouth. Brookings Papers on Economic Activity, Spring.

Kay, J. (2015). Other People's Money: Masters of the Universe or Servants of the People? Profile Books.

King, M. and Low, D. (2014). Measuring the "World" Real Interest Rate.

Kinoshita, N. (2006). Government Debt and Long-Term Interest Rates. IMF Working Papers, 06(63):1.

Kocherlakota, N. (2015). Public Debt and the Long-Run Neutral Real Interest Rate.

Laforte, J.-P. and Roberts, J. M. (2014). November 2014 Update of the FRB/US Model. FEDS Notes, 2014(0036). 
Laibson, D. (1997). Golden Eggs and Hyperbolic Discounting. The Quarterly Journal of Economics, 112(2):443-478.

Laubach, T. (2009). New Evidence on the Interest Rate Effects of Budget Deficits and Debt. Source Journal of the European Economic Association, 7(4):858-885.

Laubach, T. and Williams, J. C. (2003). Measuring the Natural Rate of Interest. Review of Economics and Statistics, 85(4):1063-1070.

Lillard, L. A. and Weiss, Y. (1979). Components of Variation in Panel Earnings Data: American Scientists 1960-70. Econometrica, 47(2):437.

MaCurdy, T. E. (1982). The use of time series processes to model the error structure of earnings in a longitudinal data analysis. Journal of Econometrics, 18(1):83-114.

Mankiw, N. G. (2000). The Savers-Spenders Theory of Fiscal Policy. American Economic Review, 90(2):120-125.

OECD (2018). OECD Tax Policy Studies: The Role and Design of Net Wealth Taxes in the OECD. Technical report.

Oh, H. and Reis, R. (2012). Targeted transfers and the fiscal response to the great recession. Journal of Monetary Economics, 59.

Piketty, T. (2014). Capital in the Twenty-First Century.

Piketty, T. and Saez, E. (2007). How Progressive is the U.S. Federal Tax System? A Historical and International Perspective. Journal of Economic Perspectives, 21(1):3-24.

Rachel, L. and Smith, T. D. (2015). Secular drivers of the global real interest rate.

Rachel, L. and Smith, T. D. (2017). Are low real interest rates here to stay? International Journal of Central Banking, 13(3):1-42.

Sajedi, R. and Thwaites, G. (2016). Why Are Real Interest Rates So Low? The Role of the Relative Price of Investment Goods. IMF Economic Review, 64(4):635-659.

Smets, F. and Wouters, R. (2007). Shocks and Firctions In US Business Cycle: A Bayesian DSGE Approach. American Economic Review, 97:586-606.

Straub, L. (2017). Consumption, saving, and the distribution of permanent income.

The U.S. Congressional Budget Office (2019). The Budget and Economic Outlook. Technical report. 
Walsh, C. E. (1998). Monetary theory and policy. MIT Press.

Wicksell, K. (1989). Interest and Prices.

Winter, C. (2016). The Impact of Government Debt on the Long-Run Natural Real Interest Rate - a Quantitative Evaluation.

Woodford, M. (2003). Interest and prices : foundations of a theory of monetary policy. Princeton University Press.

Yaari, M. E. (1965). Uncertain Lifetime, Life Insurance, and the Theory of the Consumer. The Review of Economic Studies, 32(2):137. 